\title{
39. EVOLUTION OF VOLCANIC RIFTED MARGINS: SYNTHESIS OF LEG 81 RESULTS ON THE WEST MARGIN OF ROCKALL PLATEAU ${ }^{1}$
}

\author{
D. G. Roberts, Institute of Oceanographic Sciences, Wormley \\ J. Backman, University of Stockholm \\ A. C. Morton, Institute of Geological Sciences, Leeds \\ J. W. Murray, University of Exeter, \\ and \\ J. B. Keene, University of Sydney ${ }^{2}$
}

\begin{abstract}
Leg 81 drilling results on the west margin of Rockall Plateau, combined with available geophysical data, provide the first transect of the "dipping reflector" type of passive margin. Unlike passive margins characterized by large tilted fault blocks, this type is characterized by an oceanward dipping suite of reflectors and may be the predominant type of rifted margin.

The "dipping reflector" margin can be divided into four structural zones: the ocean crust (Zone I), an outer high (Zone II), the area of dipping reflectors (Zone III), and a "landward" zone (Zone IV) of subhorizontal reflectors. The Leg 81 transect sampled Zones II, III, and IV at four sites.

The dipping reflectors were penetrated at two sites, 553 and 555. At these sites, the dipping reflectors consist mainly of subaerial tholeiitic flow basalts and minor interbedded sediments; high acoustic impedance contrasts between flows/ packets of flows and sediments may cause the reflections. The flow basalts making up much of the sequence were very probably erupted entirely within the Anomaly $24 \mathrm{~B}-25$ reversed polarity interval and possibly a good deal less. Effusive basalt eruption was succeeded by a major phase of pyroclastic volcanism that ceased just prior to Anomaly $-24 \mathrm{~B}$ and is recorded as a widespread ash-fall deposit throughout the NE Atlantic.

Two hypotheses have been proposed to explain the dipping reflectors. Mutter et al. (1982) consider that they are formed by some kind of subaerial seafloor spreading. By contrast, Roberts et al. (1979) and Hinz (1981) propose that they have formed by voluminous eruption on stretching continental crust. The Leg 81 results neigher prove nor disprove that the dipping reflectors are underlain by oceanic or continental crust, although preliminary gravity interpretation favors the latter. However, the Leg 81 results provide data and in turn constraints on reasonable models for the formation of this type of margin.
\end{abstract}

\section{INTRODUCTION}

Over the past decade, understanding of passive margin evolution has deepened as a result of the wider insight provided by integrated use of deep-sea drilling results, deep seismic refraction and reflection experiments, and innovative theoretical models of lithospheric extension (e.g., McKenzie, 1978). These results have led to the recognition of two types of rifted continental margin (Roberts and Montadert, 1980).

The first type is characterized by large tilted and rotated fault blocks bounded by listric normal faults whose polarity is consistently down toward the rift axis or continent/ocean boundary; volcanism is minor. Welldocumented examples include the Bay of Biscay and the Viking Graben (Roberts and Montadert, 1980; Ziegler, 1978). Studies of the deep crustal structure show progressive thinning of the crust toward the rift axis or continent/ocean boundary matched by an increase in subsidence (Avedik et al., 1982; Montadert et al., 1979). The-

\footnotetext{
1 Roberts, D. G., Schnitker, D., et al., Init. Repts. DSDP, 81: Washington (U.S. Govt. Printing Office).

2 Addresses: (Roberts, present address) British Petroleum Co., Brittanic House, Moor Lane, London, United Kingdom; (Backman) Department of Geology, University of Stockholm, Sweden; (Morton) British Geological Survey, Keyworth, Nottingham NG12 5GG, United Kingdom; (Murray) Department of Geology, University of Exeter, Exeter, United Kingdom; (Keene) Department of Geology, University of Sydney, Sydney, NSW, Australia.
}

oretical models (e.g., McKenzie, 1978) model the observational data set by an initial phase of subsidence associated with stretching of the lithosphere, followed by a second phase of thermal subsidence initiated at the end of rifting and/or the onset of spreading, and whose magnitude is dependent on the quantity of stretching.

The second type of passive margin is by contrast characterized by the ostensible absence of tilted fault blocks associated with the rift phase and by the ubiquitous development of a thick sequence of consistently oceanward dipping reflectors widely interpreted as a volcanic sequence. This type of margin was first identified in the Norwegian Sea (Hinz and Weber, 1976) and west of Rockall Plateau (Roberts et al., 1979). As a result of wider use and availability of multichannel seismic data, this type of margin is now known to occur widely on passive margins (and their conjugates) and may be the predominant type (Hinz, 1981; Roberts and Ginzburg, 1984, 1981; Gerrard and Smith, 1983).

The dipping reflector type of margin is not obviously explicable in terms of simple rift models, and a number of alternate and controversial hypotheses have been proposed to explain the consistent oceanward dip and the presumed volcanic origin of the sequence. One hypothesis (Mutter et al., 1982; Talwani et al., 1981; Hagevang et al., 1982) postulates that the dipping reflectors represent a sequence of sub-aerial lava flows erupted and ac- 
creted at a sub-aerial spreading axis akin to Iceland (Palmason, 1980). Others postulate that the reflectors represent a voluminous sequence of lavas and volcanogenic sediments rapidly accumulated during rifting on stretching continental lithosphere and are thus "syn-rift" deposits (Roberts et al., 1979; Hinz, 1981). Both hypotheses carry considerable implications for the position of the continent/ocean boundary, the thermal behavior of the lithosphere exemplified by the proposed volcanism, and in turn the stretching of the lithosphere.

Prior to Leg 81 , no systematic transect of drill sites allied to deep seismic data had been attempted to document the early history of the dipping reflector margin in time and space. The west margin of Rockall Plateau (Figs. 1, 2) was selected for the transect because drilling could easily penetrate the dipping reflectors and sediments deposited during the early stages of rifting of the margin and subsequent spreading. Unfortunately, not all of the objectives were attained at the four sites drilled because of a combination of operational problems and bad weather (see site chapters).

In this synthesis, we discuss the variety of results obtained during and after the leg in the context of models for the evolution of the dipping reflector type of passive margins.

\section{REGIONAL GEOLOGY}

Several independent geological and geophysical studies have confirmed the continental structures and composition of the Rockall Plateau. Laxfordian (1800 m.y.) and

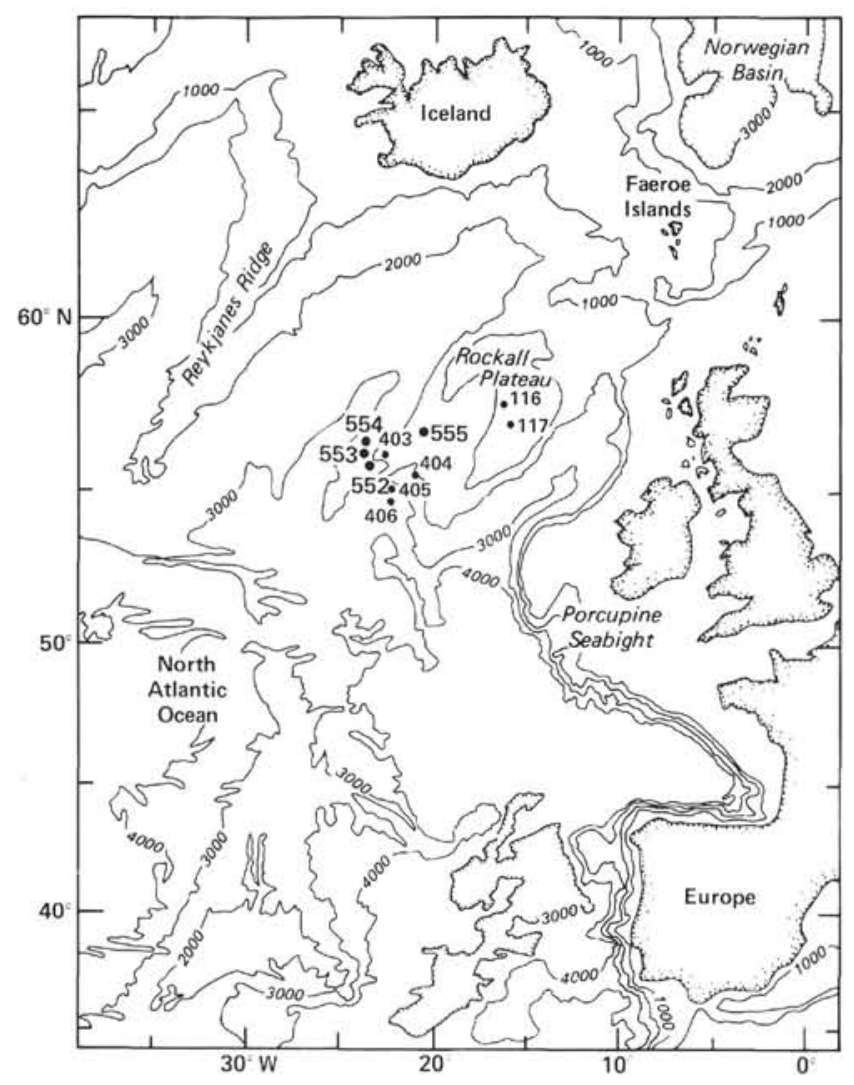

Figure 1. Location of Leg 81 sites, southwest Rockall Plateau.
Grenvillian (1000 m.y.) granulites have been dredged and drilled on Rockall Bank, while refraction studies have found continental seismic velocities and mantle depths of 33 km beneath Rockall Bank (Scrutton, 1970; Scrutton and Roberts, 1971; Roberts, Matthews, and Eden, 1972; Scrutton, 1972; Roberts, Ardus, and Dearnley, 1973; Miller et al., 1973).

To the west and southwest of Rockall Plateau, the presence of oceanic magnetic anomalies and a typical oceanic seismic structure suggests that oceanic crust underlies the deep ocean basins (Ewing and Ewing, 1958; Gaskell et al., 1958; Vogt and Avery, 1974). To the east, the body of geophysical evidence suggests that Cretaceous oceanic crust underlies part of the Rockall Trough (Roberts, 1974, 1975; Roberts et al., 1981).

The present structural isolation of Rockall Plateau was achieved in three phases. Although Triassic distension known in on-shore Scotland is the earliest rifting of direct relevance to the opening of the North Atlantic, a prolonged period of relative quiesence followed and was characterized by only minor movements. Major rifting in late Jurassic/early Cretaceous time (late Cimmerian s.l.) led to the spreading of the Bay of Biscay in Aptian time and the Rockall Trough shortly thereafter (Montadert et al., 1979; Graciansky, Poag, et al., in press).

By Anomaly 33-34 time, spreading had ceased in the Rockall Trough and the axis had shifted westward, opening the Labrador Sea and spreading Greenland-Rockall away from North America (Fig. 3A). Spreading evidently began earlier in the southern Labrador Sea than in the north and may have begun as early as the early Cretaceous (Srivastava, 1978; Keene, pers. comm., 1983). This phase of rifting and spreading created the Gibbs Fracture Zone and the equally prominent and parallel fracture zone forming the southwest margin of Rockall Plateau (Roberts, 1975; Srivastava, 1978; Roberts et al., 1979). Magnetic anomaly evidence and results from Leg 48 (Roberts, et al., 1979) suggest that this fracture zone behaved as an active continental margin transform fault between Anomaly 33-34 and Anomaly 24 time (Fig. $3 \mathrm{~B})$. It has been suggested that this offset in the margin of the embryonic Labrador Sea may have been structurally controlled by the eastward continuation of the Greenville Front (Roberts et al., 1979).

The formation of the rectilinear southwesternmost margin by rifting, spreading, and transform motion quite clearly predates in large part the adjacent NE-SW trending margin to the north where spreading began no later than Anomaly 24B (Vogt and Avery, 1974). However, it is evident that the precursor "rift" phase was contemporaneous with the spreading to the south in the Labrador Sea (Srivastava, 1978; Roberts et al., 1979). It would seem probable that some kind of Ridge-Ridgerift triple junction initially formed in the area to ultimately develop into the Ridge-Ridge-Ridge triple junction that dominated Paleogene spreading in the North Atlantic. In the context of early rift kinematics, Srivastava (1978) has observed differences in the poles of rotation for the Atlantic and Labrador Sea that suggest rifting perhaps as early as Campanian time west of Rockall. Discrepancies in the fit between Greenland and 


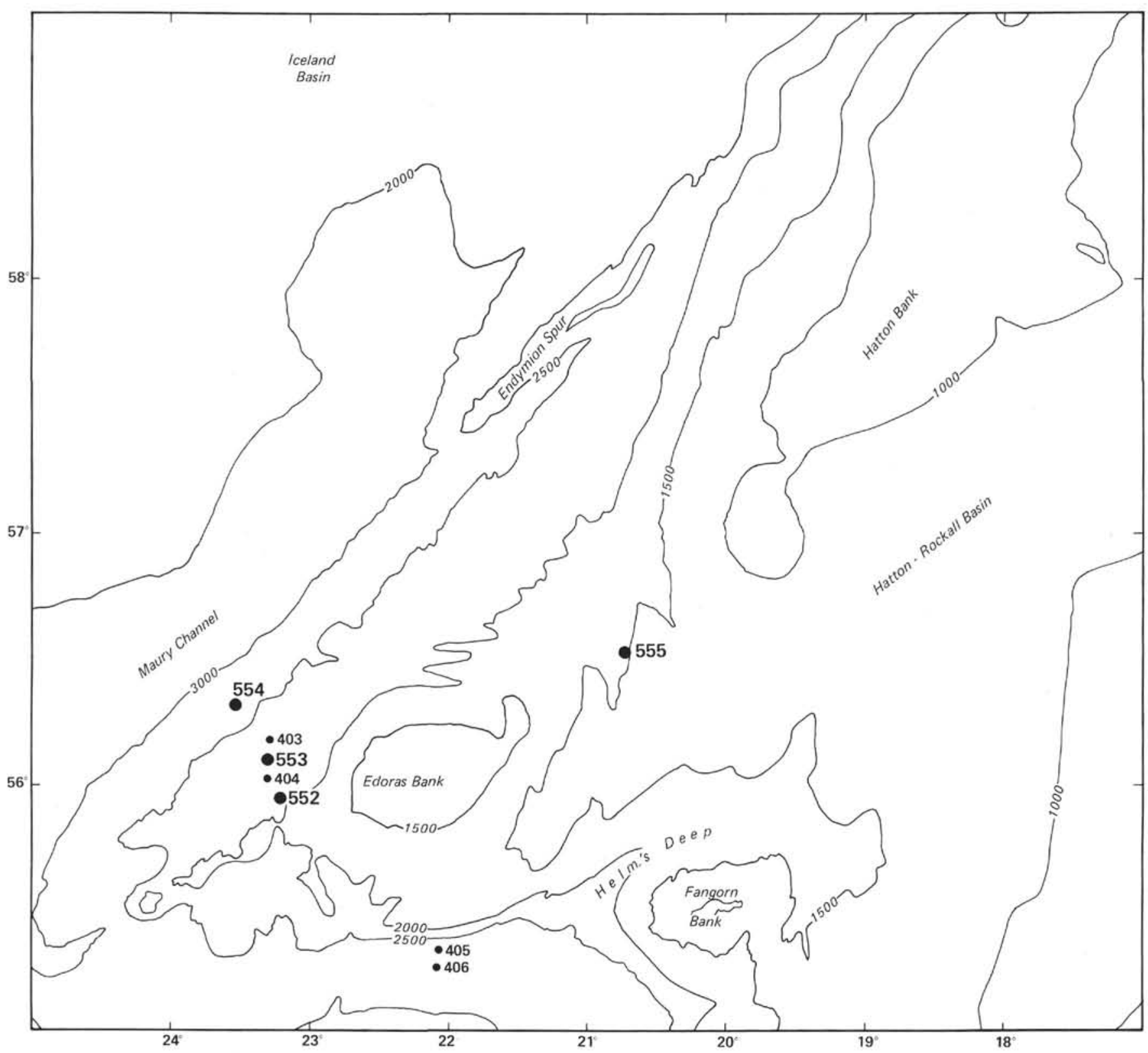

Figure 2. Location of Leg 81 and Leg 48 sites, southwest Rockall Plateau.

Rockall Plateau and rather weak evidence of pre-Anomaly 24B magnetic lineations have led to suggestions that about $60 \mathrm{~km}$ of ocean crusts might have accreted prior to Anomaly 24 (Laughton, 1971).

Active seafloor spreading between Greenland and Rockall began in Anomaly 24B time, completing the isolation of Rockall Plateau in association with the development of the triple junction mentioned earlier. Spreading continued in the Labrador Sea until about 40 m.y. when the triple junction became extinct (Vogt and Avery, 1974). On the Reykjanes Ridge adjacent to Rockall Plateau, this change was marked by a deceleration and a reorientation of the spreading to a north-south axis cut by closely spaced east-west fracture zones (Vogt and Avery, 1974). At about 10 m.y. acceleration in the spreading was accompanied by a reorientation to the present northeast/southwest axis.

\section{THE MARGIN OF SOUTHWEST ROCKALL PLATEAU: THE DIPPING REFLECTOR PROBLEM}

A regional synthesis of the geology of Rockall Plateau has been presented by Roberts (1975), and a discussion of the structure and stratigraphy of the southwest Rockall Plateau based on Leg 48 results can be found in Roberts et al., 1979.

Two sedimentary sequences separated by a prominent regional unconformity marked by reflector R4 occur throughout the area (Roberts, 1975; Roberts et al., 1979). The age of the unconformity is approximately Oligocene-Eocene. In this section, we shall restrict ourselves to discussion of the pre- $\mathrm{R} 4$ sedimentary sequence; aspects of the post-R4 sequence are discussed elsewhere in this volume. 

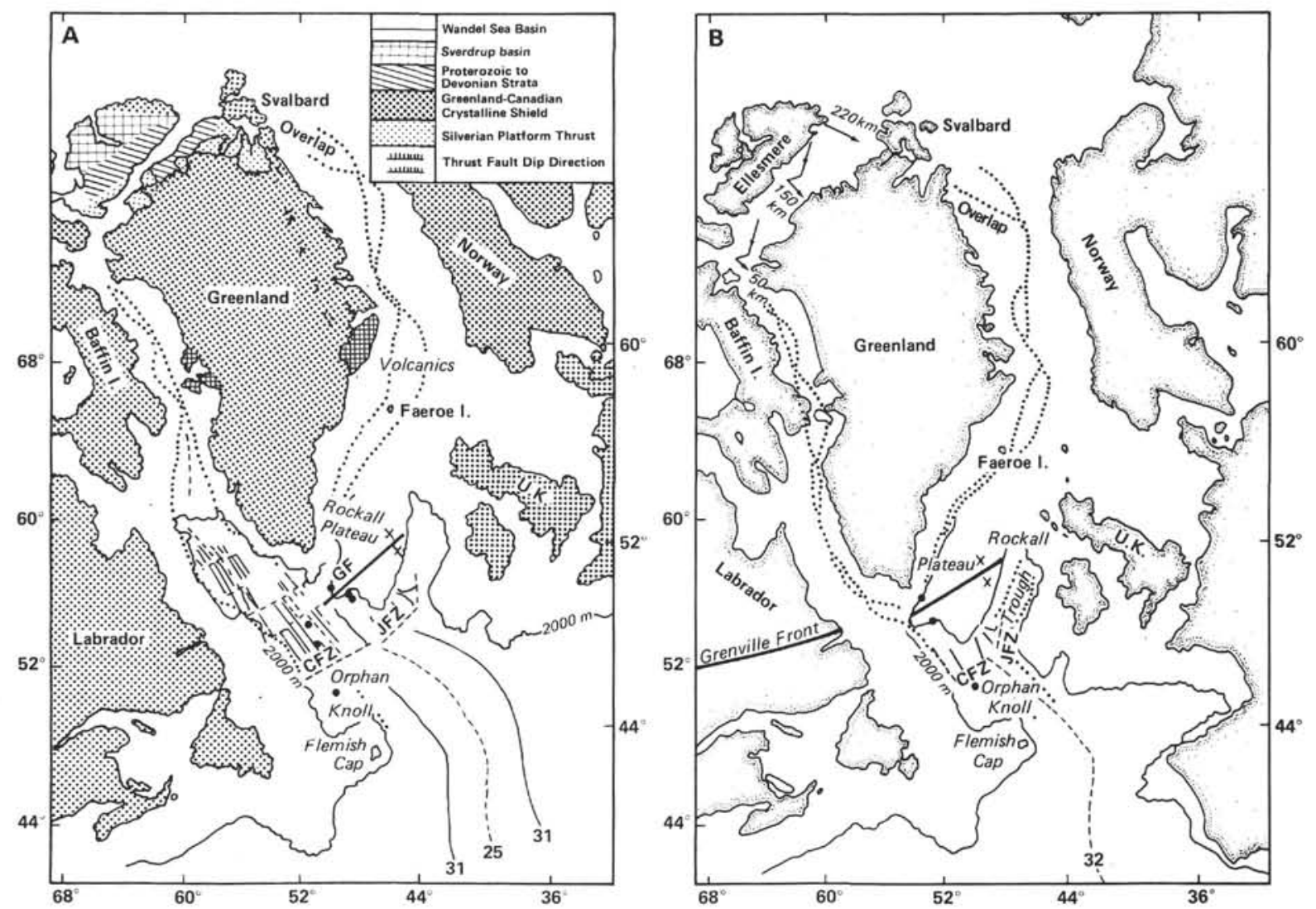

Figure 3. A. Reconstruction of the North Atlantic Ocean and Labrador Sea, Anomaly 32/33 time (Srivastava, 1978). B. Reconstruction of the North Atlantic Ocean and Labrador Sea, Anomaly 25 time.

In general terms, the west margin of Rockall Plateau consists of a series of flat-topped banks underlain by shallow "basement" and bounded by a gentle slope extending down and into the adjoining Iceland Basin. This slope is underlain by a thin post-R4 sequence above a characteristic zone of oceanward (westward) dipping reflectors. The zone of dipping reflectors can be followed the length of the west margin of Rockall Plateau and continues farther north through the western part of the Faeroes block, the Møre Basin, and the Vøring Plateau into the Lofoten Basin (Roberts et al., this volume; Hinz, 1981; Mutter et al., 1982). A similar zone of dipping reflectors occurs off east Greenland and exactly mirrors those observed on the conjugate margin of west Rockall (Featherstone et al., 1977; Larsen, in press).

Throughout the length of the margin from southwest Rockall to the Norwegian Sea, systematic variations in seismic character, reflector attitude, and structural position relative to the oldest oceanic magnetic anomalies are present and allow a simple division of the margin into four subzones (Fig. 4). Mutter (1982) has created a similar subdivision for the comparable Vøring Plateau margin. This subdivision, which can also be applied to the other occurrences of dipping reflectors recognized by Hinz (1981), facilitates description and (later in this chapter) discussion of their origin in relation to Leg 81 objectives and results.

Zone IV is the most "landward" and distant from Anomaly 24B, the oldest anomaly recognized in the adjacent ocean crust (Vogt and Avery, 1974; Roberts et al.,
1979). It is characterized by strong flat-lying reflectors (Fig. 5) and underlies the shallower banks of west Rockall Plateau, the inner part of the Voring Plateau, and outcrops as the thick basaltic flows of the Faeroe Islands (Rasmussen, 1972; Roberts, unpublished data).

Zone III is characterized by the suite of oceanward dipping reflectors (Figs. 5, 6). The transition from Zone IV to III is often marked by a break in slope coincident with a change in the attitude of the reflectors from subhorizontal to westward dipping. Along strike, there is considerable variation in the dip and structure of reflectors within Zone III on individual profiles although a westward dip is characteristic throughout. On the Vøring Plateau for example, the reflectors diverge westward and exhibit an apparent downsection and downdip increase in dip (Mutter, in press). However, on other profiles (Fig. 5) westward flattening is evident, and there is some suggestion that the divergent pattern is partly, related to an older topography or volcanic center (fig. 14A of Roberts et al., 1979).

Even in areas of detailed survey, correlation of individual reflectors for more than $15 \mathrm{~km}$ is not possible, and good multichannel seismic coverage is regionally insufficient to allow adequate structural mapping within the zone. Typically, seismic interval velocities in the dipping part of the sequence range from $3 \mathrm{~km} \cdot \mathrm{s}^{-1}$ in the upper part to $6 \mathrm{~km} \cdot \mathrm{s}^{-1}$ in the lower part.

Zone III lies entirely landward of Anomaly 24B off Rockall and East Greenland and is associated with a broad negative magnetic anomaly of substantially larger 


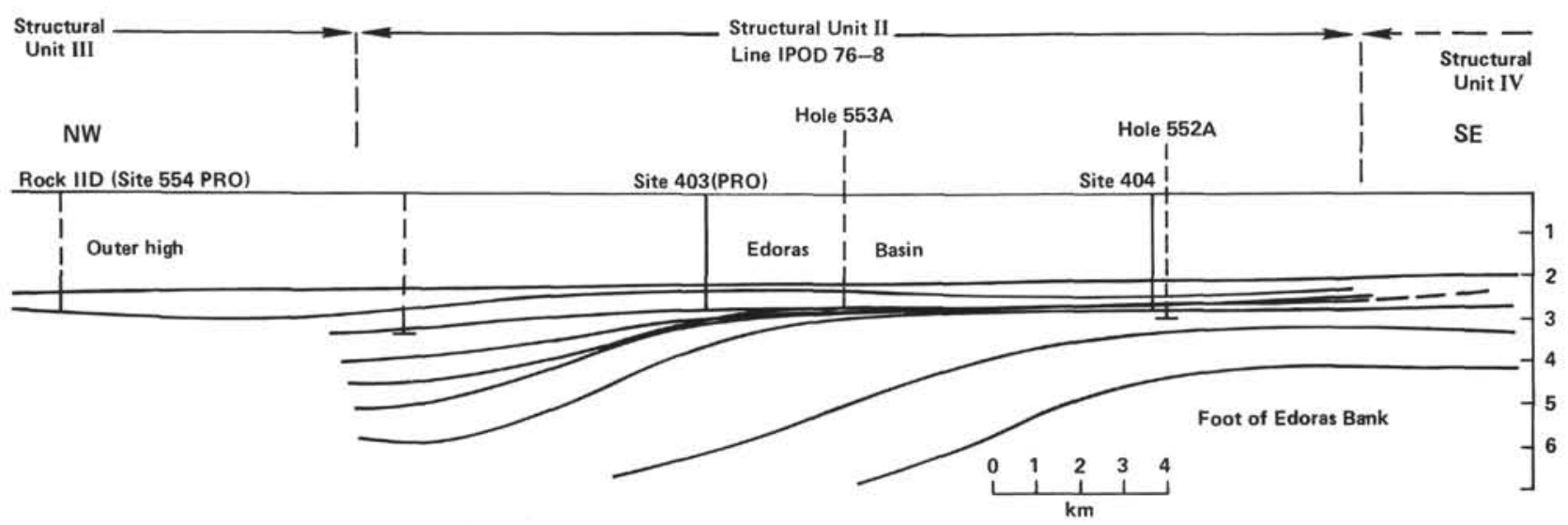

Figure 4. Structural cross-section through west margin of Rockall Plateau, showing zonation scheme and positions of Leg 48 and 81 sites.

wavelength than the adjoining oceanic magnetic anomalies (Vogt and Avery, 1974; Jones and Roberts, 1975); this is also the case in the Møre Basin (Mutter, 1982). However, in the Vøring Plateau area, Zone III is apparently overlapped by an anomaly identified as $24 \mathrm{~B}$ but remains entirely landward of the Anomaly 23-24/24B boundary (Mutter, 1982). In the Rockall area, the oceanward edge of Zone III is defined by the landward edge of the outer high comprising Zone II. As the outer high is approached, the dipping reflector sequence is apparently upthrown to the west by a series of eastward dipping faults: deposition of sediments above the dipping reflectors was evidently contemporaneous, but it is possible that the observed geometries may in part reflect westward migration of volcanic activity.

Zone II comprises the "outer high" which, in the case of west Rockall Plateau, is partly overlapped by Anomaly $24 \mathrm{~B}$. Although the outer high sometimes has significant relief (e.g., near $58^{\circ} \mathrm{N}$ ), it typically comprises a zone of generally subdued relief that is generally opaque on seismic profiles. Off East Greenland, however, the outer high has not been clearly identified and may be absent (Roberts, unpublished data; Larsen pers. comm., 1983). In the case of West Rockall, eastward prograding clinoforms off the outer high suggest that it was a positive feature. The high is flat-topped, partly overlapped by Anomaly 24B, and has been interpreted as the first oceanic crust (Roberts et al., 1979).

Zone I comprises undisputed oceanic crust characterized by strongly linear anomalies younger than Anomaly $24 \mathrm{~B}$ and has a typical oceanic refraction structure (Ewing and Ewing, 1958; Gaskell, Hill and Swallow, 1958). The top of the crystalline oceanic basement is characterized by a strong, smooth, flat-lying reflection beneath which westward dipping reflectors can be seen. In comparison to those observed in Zone III, these reflectors are weaker, discontinuous, and have apparently steeper westward dips. The western limit of the reflectors crosses the oceanic magnetic anomalies and is thus diachronous (Roberts et al., 1979).

\section{DEEP STRUCTURE OF THE WEST MARGIN OF ROCKALL PLATEAU}

Unlike the Bay of Biscay, there is no comprehensive geophysical description of the west margin of Rockall
Plateau based on deep refraction and expanded spread reflection profiles. Scrutton (1972) modelled the deep structure of the entire Rockall Plateau using deep refraction lines on Rockall Bank. His results show a 2-3 km body of anomalously high density beneath the west margin near $58^{\circ} \mathrm{N}$. To document the drill sites, one long, deep reflection profile was shot across the center west margin of Rockall Plateau together with a number of shorter seismic reflection profiles; gravity measurements were made simultaneously. The line was subsequently reprocessed by British Petroleum in an attempt to attenuate the strong multiple event from the top of the dipping reflector sequence but with only partial success. Despite this, a strong westerly dipping reflector can be followed beneath sub-horizontal reflectors for about 20 $\mathrm{km}$ before being obscured by the multiple event. Utilizing the constraints provided by the deep reflection data, previously published refraction profiles in the area (Gaskell, Hill, and Swallow, 1958), and the density data measured at Site 553, the deep crustal structure has been modelled assuming the presence of oceanic (Fig. 7, Model A) or continental crust (Fig. 7, Model B) beneath the lavas (Roberts and Ginzburg, 1984).

Model A uses a standard oceanic crustal section as far as the landward edge of Zone III, here assumed to be continent/ocean transition. Further east, thick lavas are assumed to rest on thin continental crust. The difference between the observed and computed anomaly is substantial and implies a lighter crustal column. Model B by contrast assumes that oceanic crust is only present as far east as the landward limit of Anomaly 24B so that the inner edge of the outer high (Zone II) is identified as the continent/ocean transition. In this model, the agreement between observed and calculated anomalies is good and indicates that the mass balance can be satisfied by the presence of stretched continental crust at idepth.

It should be stressed that these models are crude in that deep refraction data are not available to constrain the position of the Moho, or velocity/density gradients in the lower part of the crust beneath the lavas. Nonetheless, the depth of penetration of the reflection profiles places some constraint on the possible range of variations in crustal structure that can be realistically proposed for the lower crust in this case. 

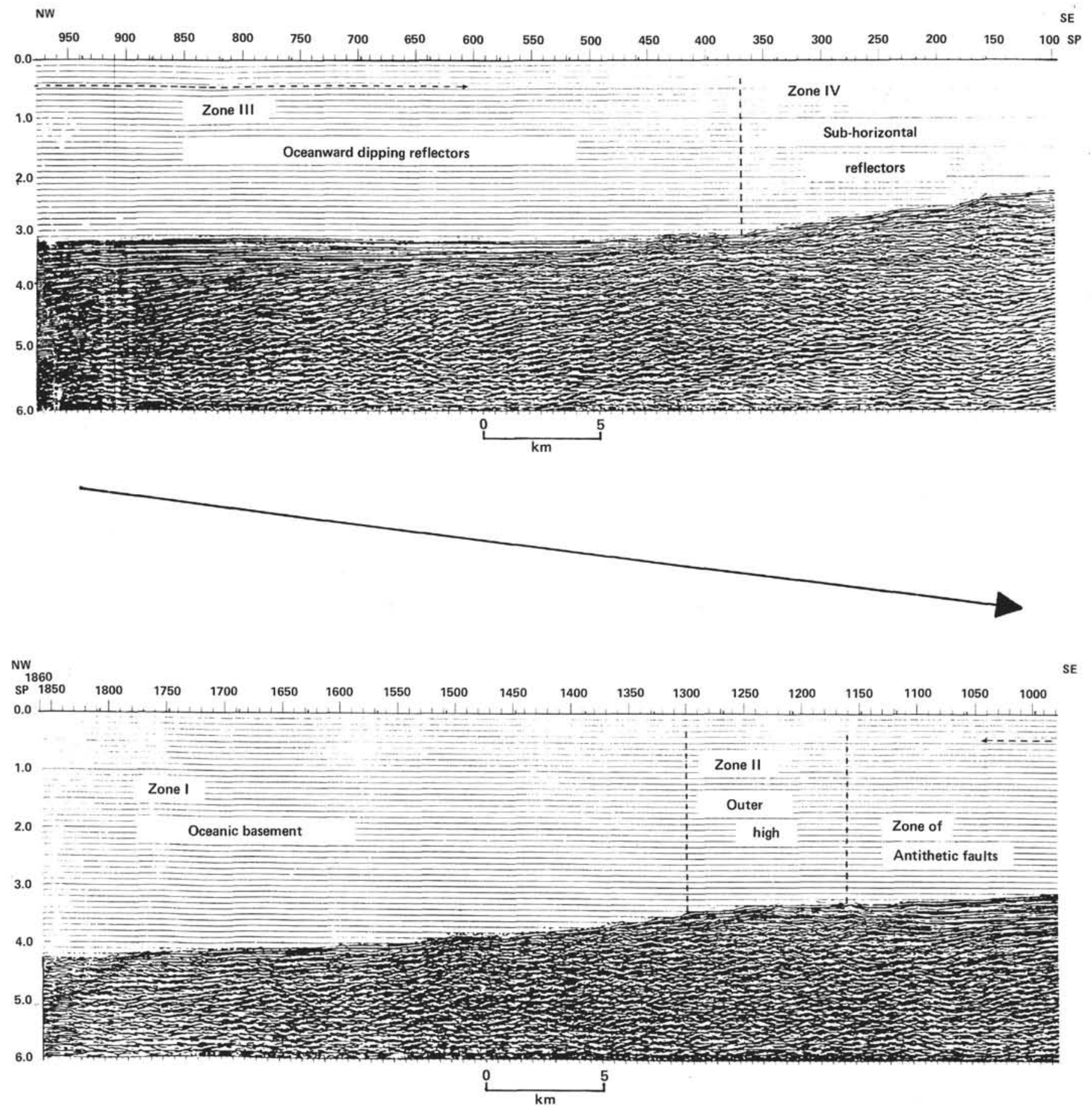

Figure 5. Regional seismic reflection across west margin of plateau. Line 10S-2 located in Fig. 6. (Dashed line indicates location of migrated section of this line shown in Fig. 14.)

It is important to compare these results with the limited deep refraction and reflection data available for the closely comparable Vøring Plateau margin. In the area of Zone III (Zone II of Mutter, 1982), a distinct break in velocity structure occurs in thickened "oceanic" crust and is interpreted as the boundary between dikes and lavas; this boundary shoals seaward. In the zone landward of the dipping reflectors, a low velocity zone was detected above a prominent reflector, horizon "K." Horizon " $\mathrm{K}$ " is interpreted by Mutter et al. as the dyke-lava in- terface beneath the mixed sediments and volcanics of the low velocity zone. Mutter et al. (1982) consider that pure continental crust does not lie seaward of the landward edge of Zone IV. However, no gravity models of deep structure incorporating those results have been reported.

The preceding review demonstrates the important need to obtain deep wide-angle refraction and reflection data to constrain the range of models that are possible as a result of the non-uniqueness of gravity modelling. We 


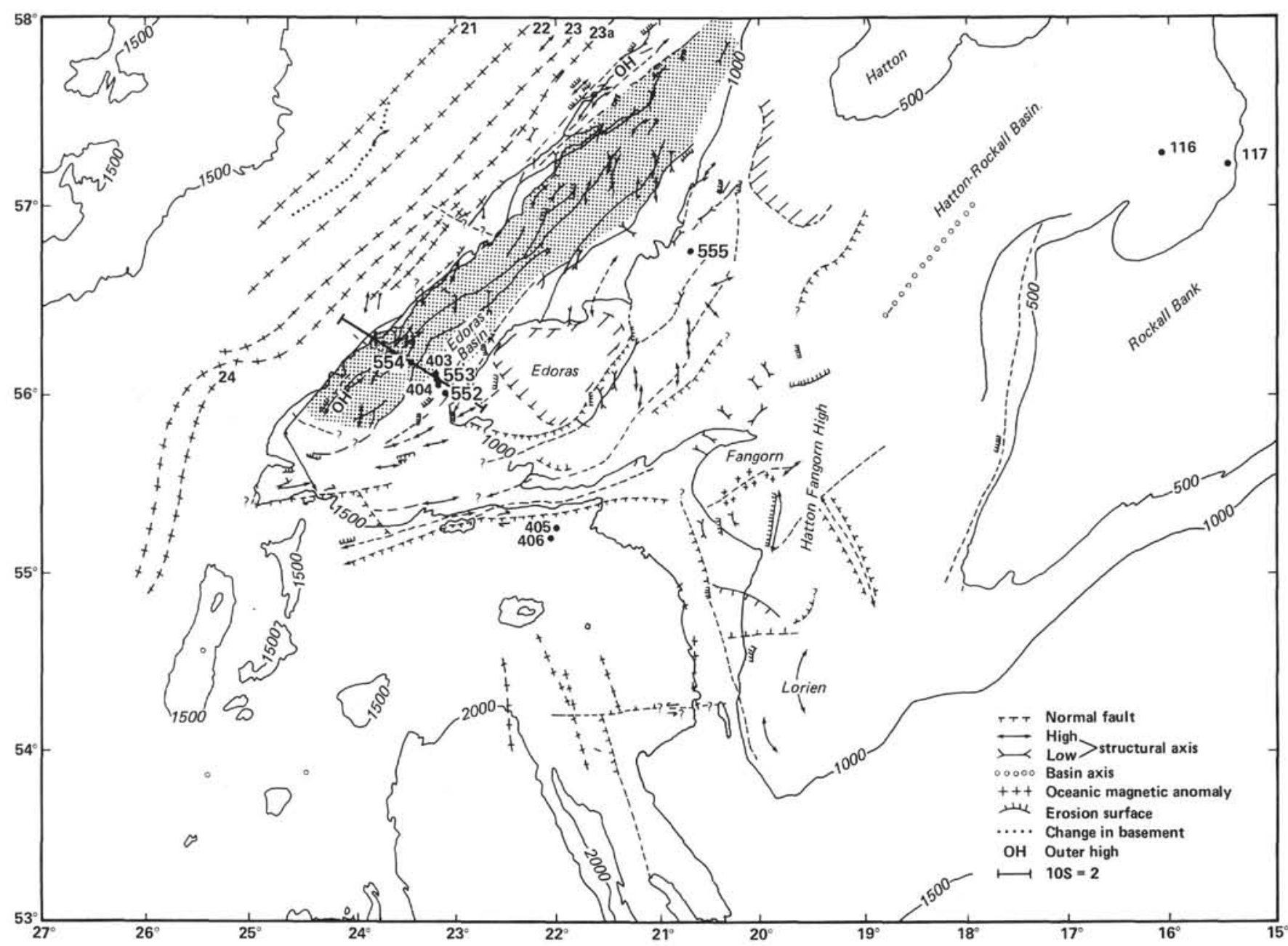

Figure 6. Structural sketch of western Rockall Plateau (from Roberts et al., 1979). Shaded area indicates Zone III.

shall later compare these models in the context of the various results from the leg.

\section{SUMMARY OF DRILLING RESULTS}

The biostratigraphy, principal lithologies, and lithologic units of the far sites are summarized and correlated in Figures 8 and 9. Only the Paleogene interval is reviewed here, although brief reference to the Neogene is made later in discussion of the subsidence history of the margin. The structural subdivision of the margin outlined in the preceding sections forms the basis of the review of Paleogene stratigraphy.

\section{Zone IV: Site $\mathbf{5 5 5}$}

Site 555 was located on the col between Hatton Bank and Rockall Bank at the shallowest point of transect. The late Paleocene-early Eocene section penetrated at the site comprises two lithologic units and eight subunits.

The lowest lithologic unit, IV, consists of basaltic lava flows and hyaloclastics and interbedded tuffs. Three subunits are identified from the presence or absence of interbedded sediments. The unit is of reverse polarity and the interbedded sediments are of NP9 age. The basal subunit IVc consists of a single massive flow unit. Subunit IVb consists of tuffs and lapilli tuffs interbed- ded with micaceous and feldspathic sandstones, siltstones, and mudstones, and three thin basalt flows; sedimentary structures within the unit suggest an upward change from lower- to higher-energy environments.

Morton (this volume) has documented the presence of two heavy mineral associations. Association 3 consists of garnet, augite, apatite, edenitic, and paragasitic amphiboles, and has a provenance on southwest Rockall Plateau. Mineral association 2, consisting of epidote group minerals including piedmontite, amphiboles of actinolite, actinolitic hornblende, and magnesio-hornblende compositions, was possibly derived from southeast Greenland. However, fission track ages determined on apatites and sphenes extracted from these sediments group at $56 \pm 3$ m.y., $199 \pm 13$ m.y., and $138 \pm 95$ m.y., suggesting a more complex provenance (Duddy et al., this volume). The ages of $56 \pm 3 \mathrm{~m}$.y. lie close to the radiometric dates of $52.3 \pm 1.7$ and $54.5 \pm 2.0 \mathrm{~m}$.y. obtained from basalts in Unit IV, suggesting penecontemporaneous erosion (Macintyre and Hamilton, this volume). The ages of $97 \pm 3$ and $199 \pm 13 \mathrm{~m}$.y. suggest the existence of Cretaceous igneous centers like Helen's reef (Roberts et al., 1973) and as yet unknown centers of Mesozoic age. Finally, the $1381 \pm 95$ m.y. ages are compatible with a Rockall $\sigma$ Greenland provenance for 
D. G. ROBERTS ET AL.
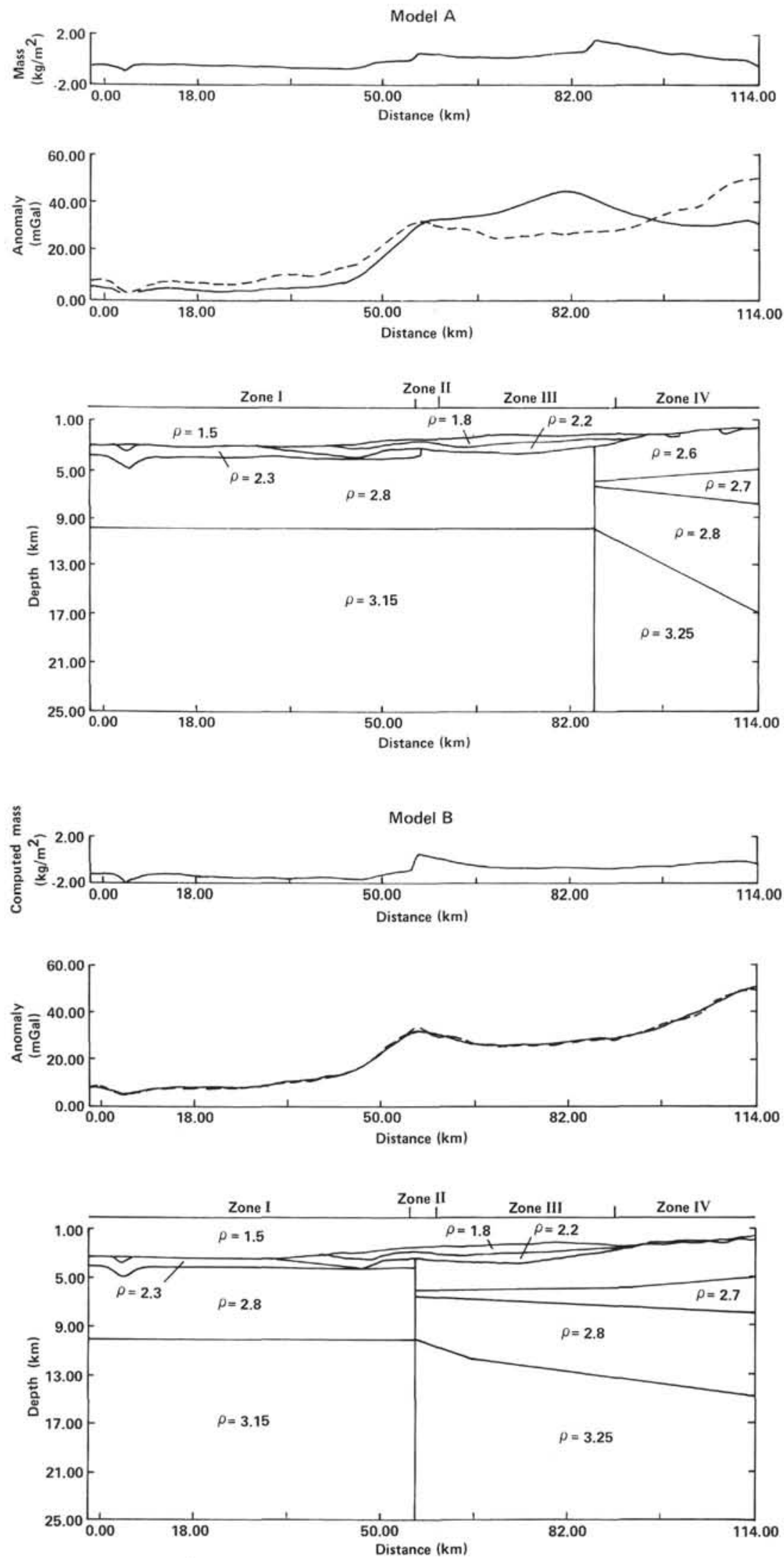

Figure 7. Gravity model A of deep crustal structure along the line of the regional seismic profile shown in Figure 5. Model assumes oceanic crust to the Zone III/IV transition. Gravity model B of deep crustal structure along the line of the regional seismic profile shown in Figure 5. Model assumes thinned continental crust extends to the inner edge of the outer high. 


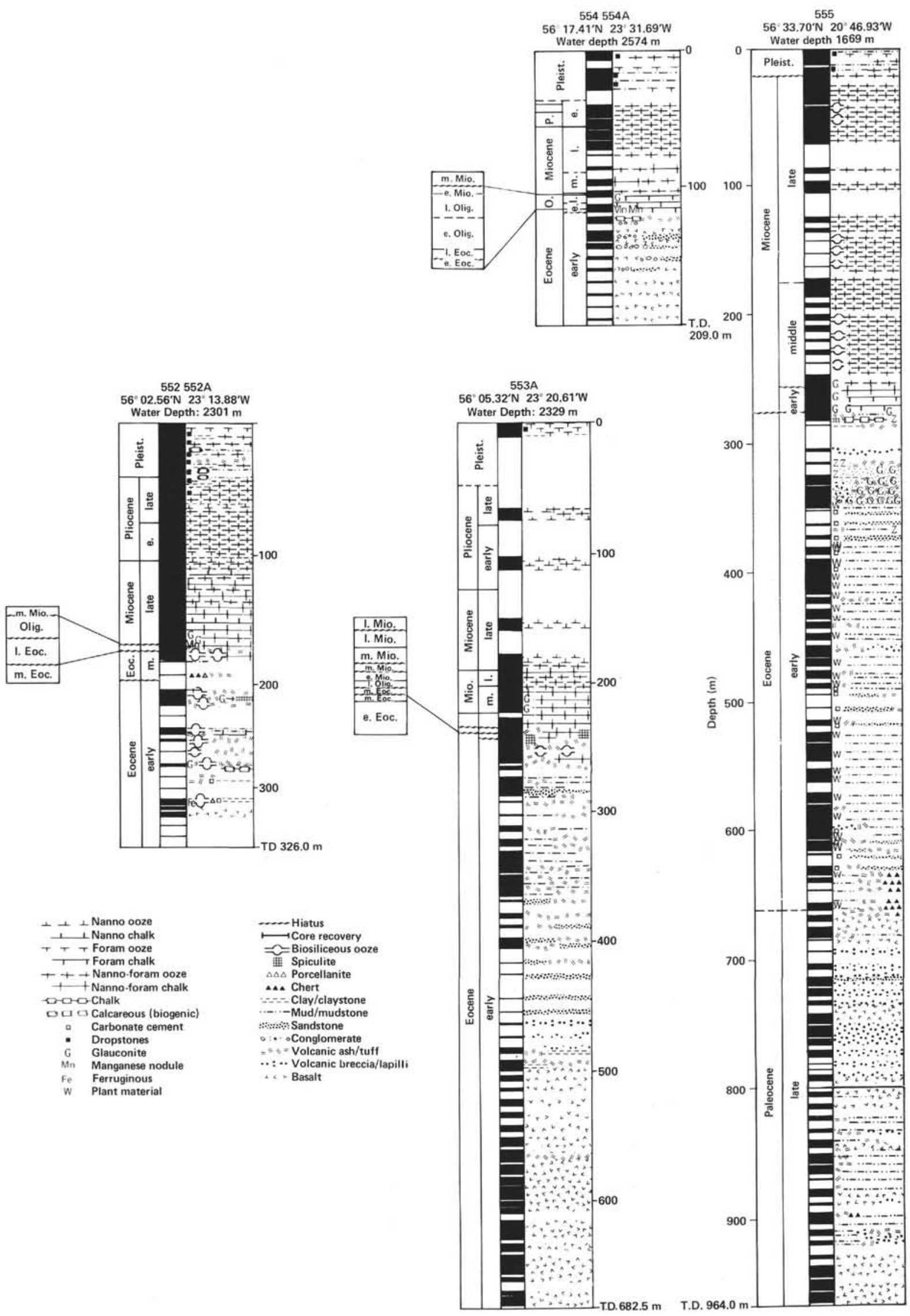

Figure 8. Stratigraphic summary of Leg 81 sites. 


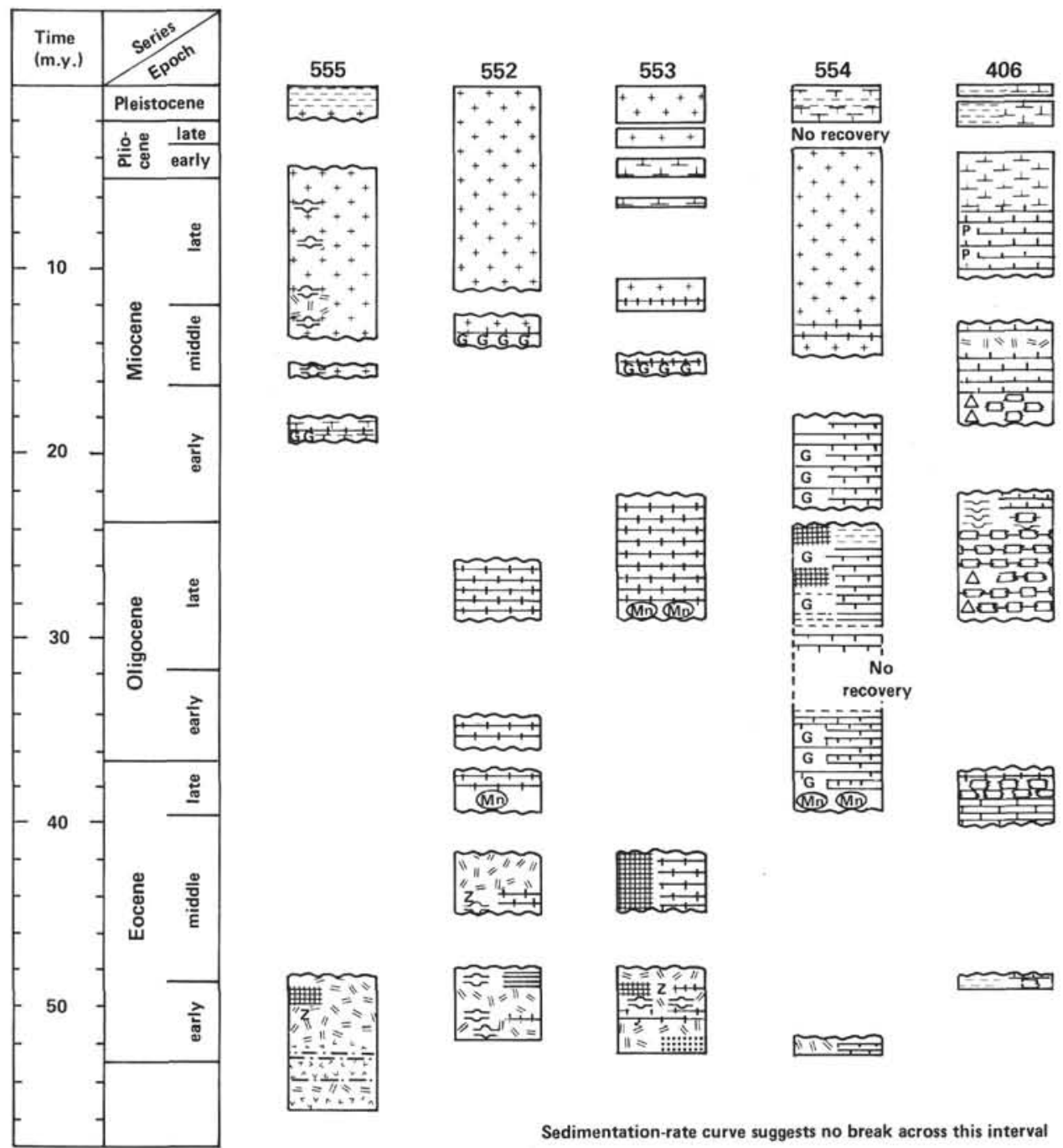

Figure 9. Chronostratigraphic summary of Leg 81 sites.

the metamorphic minerals (see Roberts et al., 1972, 1973).

The upper Subunit IVa consists of seven single and composite pillow lava flow units ranging in thickness from 26 to $140 \mathrm{~cm}$ interbedded with hyaloclastie which forms the bulk of the subunit. Eruption in shallow marine waters is suggested by the depositional environment of underlying Subunit IVb and by thermal alteration of clay minerals near the basalts (Despraires et al., this volume). Petrographic and geochemical studies of the Site 555 lavas demonstrate their tholeiitic origin (Richardson et al., this volume; Harrison and Merriman, this volume; Joron et al., this volume). Richardson et al. suggest that the Site 555 lavas are the products of $\mathrm{Zr}$-poor and $\mathrm{Zr}$-rich magma types. Joron et al. note that the basalts from all the Leg 81 sites are LREE-depleted oceanic tholeiites. However, at Site 555 the Th/Ta ratio is close to 2-3 and is significantly different from values found in deep oceanic tholeiites and the other Leg 81 sites. Kharbouch (1982) and Beziat (1983) have observed such ratios in continental margins. However, Macintyre and Hamilton (this volume) observe that initial ${ }^{143} \mathrm{Nd} /$ ${ }^{144} \mathrm{Nd}$ ratios lie in the very restricted range of 0.512920 \pm 19 to $0.513026 \pm 24$ and initial ${ }^{87} \mathrm{Sr} /{ }^{86} \mathrm{Sr}$ ratios from c. 0.703 to 0.705 , reduced by acid leaching to $0.7026 \pm$ 4 to $0.70384 \pm 4$, indicating a MORB-type origin.

The sediments of overlying Unit III consist of widely varying lithologies loosely transitional between the pelagic oozes of Unit II and the basalts and hyaloclastites of Unit IV below; the unit is equivalent to Subunit IVb-f of Site 553.

The basal Subunit IIIe consists primarily of volcanic tuff and lapilli tuffs deposited in inner-shelf depths. Overlying Subunit IIId comprises brownish black mudstones with interbeds of feldspathic sandstone deposited in an environment that shoaled from inner shelf to brackish intertidal marsh. A short normal polarity event (Krumsiek and Roberts, this volume) allows for correlation of Subunit IIId to Unit IVd of Site 553. Subunit IIIc consists of tuffs and lapilli tuffs interbedded with carbonaceous mudstones of NP10 age. The absence of microfossils and marine fauna suggests subaerial or estuarine deposition in marked contrast to the depths of deposition of $25-100 \mathrm{~m}$ in its lower part (Murray, this volume). The transition from Subunit IIIc to IIIb is marked by the appearance of abundant glauconite and 
the disappearance of the heavy mineral association 2 derived from Greenland. These changes, also observed at Site 553 (and the Leg 48 sites), occur in the upper part of NP10 and just below the base of Anomaly-24B which is found just above the first appearance of glauconite. These changes probably indicate transgression caused by increased subsidence, very probably initiated at the transition from rifting to spreading between Greenland and Rockall Plateau. Water depths increased progressively throughout deposition of Subunit IIIb from 25100 to $100-200 \mathrm{~m}$ (Murray, this volume).

The overlying Subunit IIIa was characterized by poor recovery. The principal lithologies recovered were vitric spiculites, tuffs, and bioclastic limestones of NP11 age. Poorly preserved benthic forams suggest increased water depths of $150-200 \mathrm{~m}$ but, by contrast, higher energy conditions are suggested by thick walled oysters. The lower boundary of the unit falls within Zone NP11 but is of normal polarity in its upper part. Magneto- and biostratigraphic correlation as well as the comparable lithologies suggest that IIIa is the lateral equivalent of Subunit IVb at Site 533 .

\section{Zone III: Sites $\mathbf{5 5 2}$ and $\mathbf{5 5 3}$}

Sites 552 and 553 were drilled in Zone III and together provide a composite section of the sedimentary section above the lavas successfully penetrated at Site 553 . Although submarine basalt overlain by reddened sediments was cored at total depth at Site 552, this basalt is thought to be younger (upper NP10 to lower NP11) than the basalts cored at Site 553 .

At Site 553,181.5 m of basalt were drilled and cored to a total depth of $682.5 \mathrm{~m}$ when drilling was terminated by a mechanical failure. The basalts correspond to the uppermost part of the dipping reflector sequence observed on the seismic profiles. Typical flow units consist of a weathered scoriaceous agglomeratic top passing downwards into vesiculated basalt, massive foliated basalt, and, in turn, the highly vesiculated base of the flow. Three basalt subunits were identified from the physical properties data, downhole logs, and paleomagnetic measurements (see Site 553 chapter, this volume; Krumsiek and Roberts, this volume).

The lowermost basalt unit (Subunit Vc) is characterized by higher gamma response and an increase in susceptibility and intensity of magnetization with depth. Interpretation of the resistivity log suggests that 14 flows are present and all were cored. The top of the subunit may correspond to the top of the suite of dipping reflectors below the topmost reflector (2) of the sequence. The thinner flows and presence of slickensided fractures may account for the wide range of sonic velocities measured in the flows 3.1 to $5.8 \mathrm{~km}^{-1}$. Unrecovered intervals between the flows are characterized by a higher gamma response and porosity that may indicate interbedded sediments (or paleosols) flushed out by the high drilling pressures.

Overlying Subunit $\mathrm{Vb}$ is characterized by lower gamma response, low susceptibility, and higher intensites of magnetization as well as fewer but thicker flow units: only five lava units were identified from the resistivity log. The rare increased gamma response at the tops of the flows suggests that sediments, tuffs, or weathered zones are sparse; a deeply reddened "tuff" towards the top of the unit is apparently a hyaloclastite. Fracturing within the flow units is shown by displacement of the ILD and ILM logs and directly by horizontal and inclined $\left(50-80^{\circ}\right)$ fractures, some of which show evidence of displacement. Sonic velocities are higher and range from 3.5 to $6.0 \mathrm{~km}^{-1}$ in accord with the comparatively massive nature of the flows, although all show the typical structure of flows observed in Subunit Vc.

Subunit Va comprises the uppermost part of the basalt sequence. As many as 12 flow units are suggested by the resistivity log of which 9 were identified in the cores. Increased gamma response towards the top of the flow units as well as decreasing sonic velocity may be indicative of sedimentary interbeds or the scoriaceous tops of the flows. Fracturing is again suggested by divergence of the ILD and ILM logs. Some velocities range from 3.4 to $4.7 \mathrm{~km}^{-1}$.

Paleomagnetic measurements indicate that the basalts are all reversely magnetized and exhibit five cyclical variations in inclination that may record secular variation (Krumsiek and Roberts, this volume) (Fig. 10). The upward increase in the number and thickness of flows may suggest accelerated extrusive activity during the terminal stages of the volcanism. Radiometric data from the basalts yielded a large scatter of ages, but when treated with the results from Site 555 yielded an average age of $55.2 \pm 3.3$ m.y. (Macintyre and Hamilton, this volume). In conjunction with the biostratigraphy of the overlying interval and the reversed polarity of the basalts, this age suggests eruption during the reversed polarity interval Anomaly 24B-25.

Detailed studies of the petrography and geochemistry of the basalts are reported in this volume by Richardson et al., Joron et al.; Macintyre and Hamilton, Harrison and Merriman, and by Desprairies et al. Site 553 basalts show little variation in petrography, mineralogy, or in major and trace element composition. The basalts comprise plagioclase-clinopyroxene-tholeiites formed by early crystallization of plagioclase. Many of the basalts exhibit varying degrees of alteration shown by argillization of the primary minerals. Infill of vesicles by smectite and celadonite indicates that the alteration accompanied or shortly followed eruption of the flows and may have been accelerated through metasomatism or hydrothermal alteration by circulating fluids in the lava flows. Subaerial weathering can be inferred from the presence of nontronite, but it seems certain that it was followed by prolonged contact with circulating seawater-a process that may account for the high initial ${ }^{87} \mathrm{Sr} /{ }^{86} \mathrm{Sr}$ ratios of c. 0.703 to c. 0.705 measured prior to acid leaching (see Macintyre and Hamilton, this volume). Harrison and Merriman (this volume) note that the sequence of minerals is compatible with seawater rock interaction at falling temperatures below $200^{\circ} \mathrm{C}$ and probably $150^{\circ} \mathrm{C}$. Desprairies et al. (this volume) have made a more detailed study of alteration minerals and identify two types of alteration products; a saponite-celadonite association infilling vesicles and a smectite (beidellite) association 

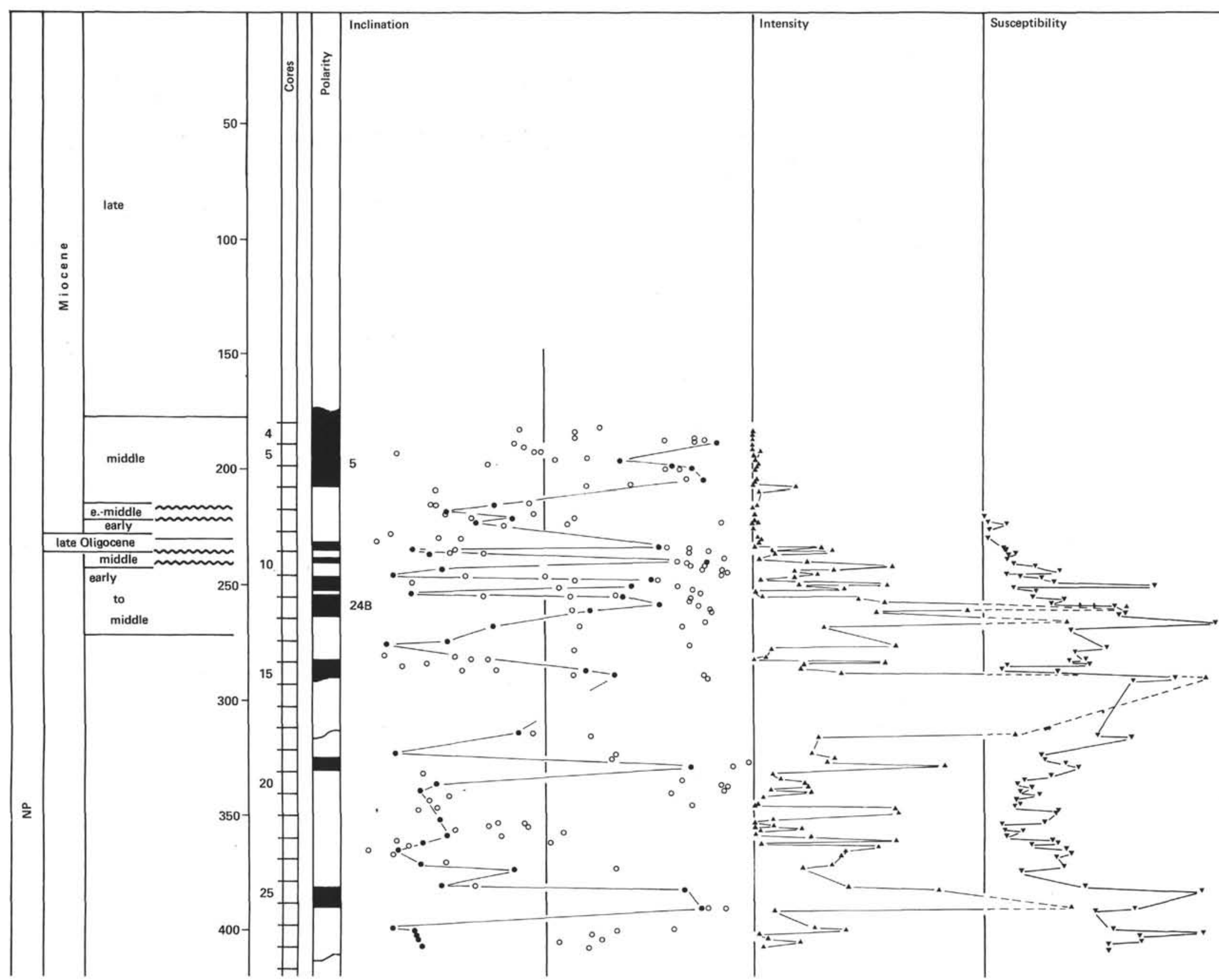


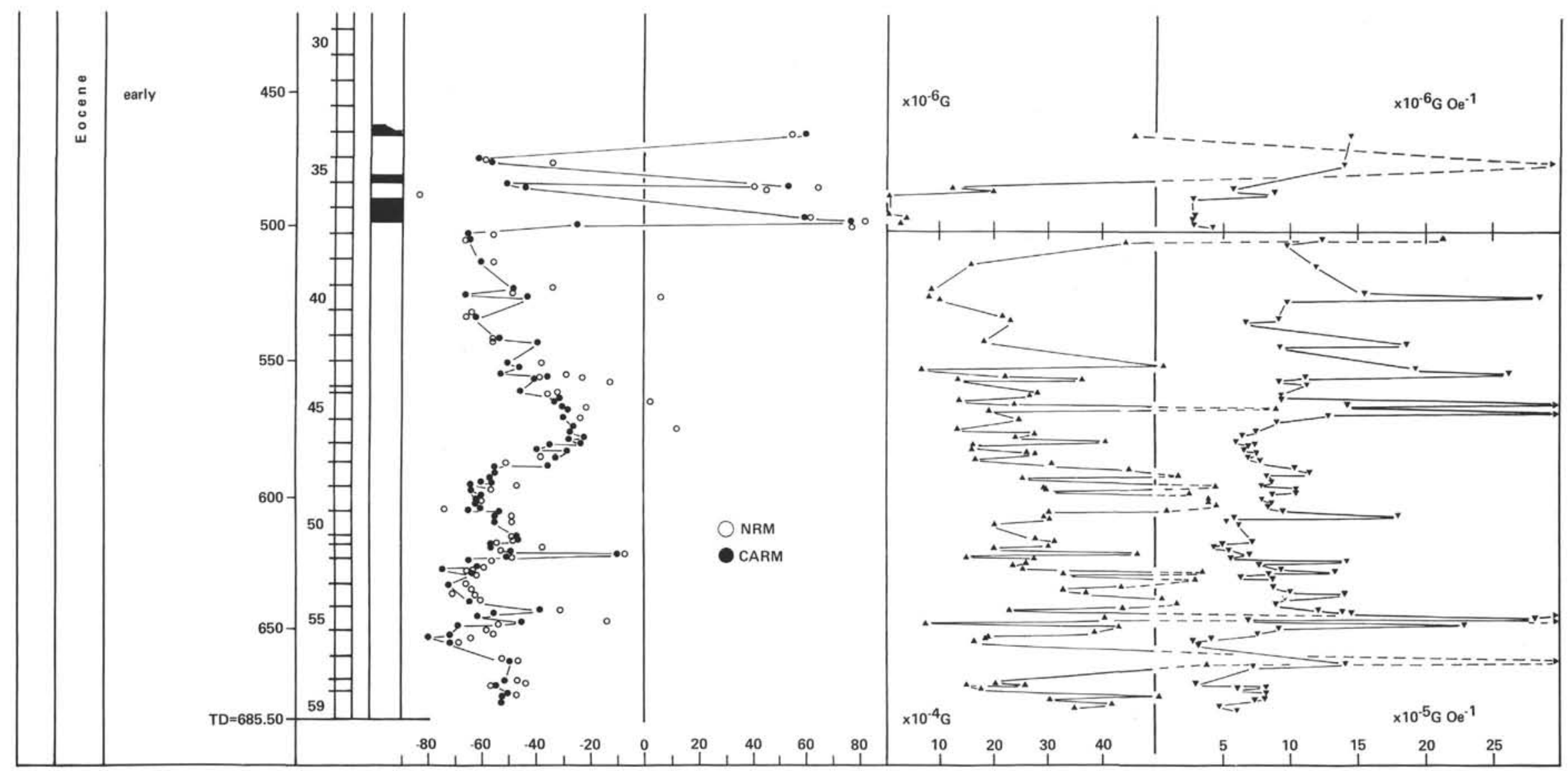

Figure 10. Summary of paleomagnetic data, Sites 552,553 . Note cyclical variations in inclination below $500 \mathrm{~m}$. 
with hematite in the groundmass. Trace-element studies indicate that the celadonite was derived from the saponite and both are hydrothermal alteration products; crystallization of the $\mathrm{Mg}$-saponite took place at $100^{\circ} \mathrm{C}$ and the celadonite at $40^{\circ} \mathrm{C}$. By contrast the chemistry of the beidellites and association with hematite suggests sub-aerial erosion or interaction with sediments between flows. However, Despraires et al. conclude that hydrothermal alteration preceded sub-aerial weathering of the basalts at Site 553-a conclusion supported by the poor crystallization of hematite and nontronite.

Major and trace-element chemical studies of the basalts (Richardson et al. and Joron et al., (this volume) and $\mathrm{Sr}$ and $\mathrm{Nd}$ isotope studies (Macintyre and Hamilton, this volume) show that the basalts are tholeiites of MORB affinity. Joron et al. demonstrate that the basalts are strongly LREE-depleted and extremely depleted in the most hygromagmaphile elements $(\mathrm{Th}, \mathrm{Ta}$, $\mathrm{La}, \mathrm{Nb}$ ). Trace alkali elements (Maury et al., in press) are similar to those drilled at the continent/ocean boundary of the Celtic Sea and to the Preshal Mhortype tholeiites of the Hebridean Province (Thompson, 1982).

The important conclusion is that typically depleted MORB's can occur on mid-ocean ridges as well as in the early stages of rifting and/or spreading. However, the chemistry of these basalts is notably different from basalts of flood basalt parentage observed on the European, African, and American margins. Nonetheless, some similarities do exist with other basalts in the neighborhood. For example, Schilling and Noe-Nygaard (1974) described an abrupt change from LREE-enriched to LREE-depleted patterns near the boundary of the Middle and Upper Series of the Faeroes Plateau Basalt and attributed the change to a transition in magmatic regime from plume-derived to oceanic that has clearly occurred in a well-established continental setting. Thompson (1982) has described LREE-depleted basalts from a continental setting in Skye. Richardson et al. (this volume) have compared the trace element compositions of Leg 81 basalts with basalts from the adjoining ocean floor and nearby margins. They note that the Leg 81 basalts are again different in the Faeroese, Greenland, and Icelandic basalts, although the latter three are similar. Richardson et al. invoke mantle heterogeneity as the cause of these differences and also note the presence of two distinct $\mathrm{Zr}$-rich and $\mathrm{Zr}$-poor magma types of MORB affinity at the Leg 81 sites; they also note that the present distinction in geochemistry between the basalts south of Iceland and those near the Gibbs Fracture was already well established at the time of rifting.

The Paleocene-Eocene section overlying the basalts at Site 553 consists of one unit, IV, divided into six subunits based on background sediment type. Like the equivalent unit at Site 555, considerable variation in the quantity of volcanogenic sediment is present, and there is a clear and rapid increase in water depths during deposition of the upper part of the unit.

The lowest subunit, IVf, is of NP9/10 age and predominantly of reverse polarity, although one short normal polarity event may be present just above the basalts.
The NP $9 / 10$ boundary probably lies just above the base of the unit and close to this normal polarity event. The basal sediments lie in sharp contact with the underlying basalt, and no reddening of the basalt is evident (cf. Site 552). They comprise a coarse-grained and strongly crossbedded sandy tuff that may represent a basal transgressive deposit and a hiatus of unknown duration is thus inferred between eruption of the basalt and that deposition. Principal lithologies in the rest of the subunit are mainly tuffaceous mudstone with volcanic tuff and lapilli interbeds. Deposition in intertidal marsh conditions is suggested by the fine laminae of the mudstones, benthic forams (Murray, this volume), and a macrofauna consisting of thin-shelled bivalves, gastropods, and bivalves.

Overlying Subunit IVe consists almost wholly of lapilli tuffs composed of lapilli up to $2 \mathrm{~cm}$ in diameter. By contrast, the overlying Subunit IVd consists largely of feldspathic, micaceous, and slightly tuffaceous mudstones. The abundance of heavy mineral association 2 suggests derivation from Southeast Greenland. The subunit is barren of microfossils. The overlying Subunit IVc records two important changes in the geological history of the west margin. The first is reflected in the large abundance of volcanogenic material compared to subunits above and below and the second in the disappearance, at the top of the unit, of the heavy mineral association 2 of Morton (this volume). The unit is of NP10 age throughout and is predominantly of reverse polarity although two short normal polarity events are present. The background sediment of the subunit is highly tuffaceous because of reworking and bioturbation, but consists mainly of terrigenous mudstones and sandy mud. Heavy minerals of association 2 derived from the metamorphic basement of Southeast Greenland are abundant. The illite-smectite-kaolinite suite in the terrigenous sediments represents alteration products of the detrital suite. Disseminated carbonaceous material occurs throughout (Kaltenback, this volume). Scouring, cross laminae, and intraclasts provide evidence for fairly strong current activity.

Benthic forams show a progressive upward decrease in depth and environment of deposition compatible with the sedimentological observations. Mid-shelf depths of 75-100 m (Core 24) shoaled to inner-shelf depths of less than $75 \mathrm{~m}$ (Cores 23-18) with episodic changes in salinity from normal to slightly brackish. A trend to increasing water depths of $50-100 \mathrm{~m}$ is seen toward the top of the unit. An abundant macrofauna of bivalves, gastropods, and serpulids is present, with changes in energy or proximity to shore indicated by the presence of thickshelled oysters (Core 19-slightly brackish inner shelf; see Murray, this volume) among the more abundant thin-shelled bivalves.

Morton (this volume) identifies two subphases of volcanic activity within the abundant tuffs of the unit. Subphase $2 \mathrm{a}$ contains 36 tuffs whose air fall origin is demonstrated by upward fining grain size. Thirty-six tuffs and lapilli tuff beds occur in the lower phase (34 were noted at nearby Site 403 ). The later $2 \mathrm{~b}$ phase is represented by a single unit of highly reworked and biotur- 
bated lapilli tuff with maximum clast diameters of up to $2 \mathrm{~cm}$ and a matrix of blue green celadonite. Volcanic glasses of the tuffs show basic and intermediate compositions. Lithologies represented in the lapilli vary widely from palagonitized glass to basalt and vesicular pumice. Post-depositional phases include smectite, celadonite, clinoptilolite, phillipsite, modernite, and analcime. The celadonite occurs within the thick lapilli tuff of phase $2 \mathrm{~b}$ as a replacement of the ground mass. Its presence suggests a low temperature hydrothermal regime that postdates both the volcanism and the formation of syngenetic glauconite. The normal polarity event recorded at this level may reflect an overprint acquired at time of celadonite authigenesis in (?) Anomaly-24B time (Morton, this volume; Krumsiek and Roberts, this volume). Microprobe studies of the alteration products of the volcanic glasses show two distinct trends. Typically samples from the phase 2a tuffs show substantial loss of $\mathrm{Ca}$, as well as $\mathrm{Si}, \mathrm{Al}, \mathrm{Na}$, and $\mathrm{K}$ and a relative gain in $\mathrm{Fe}$ and $\mathrm{Mg}$. However, samples from the phase $2 \mathrm{~b}$ tuff show loss of $\mathrm{Ca}, \mathrm{Si}, \mathrm{Al}, \mathrm{Mg}$, and $\mathrm{Na}$ but relative enrichment of $\mathrm{Fe}$ and $\mathrm{K}$. These trends are typical of those found in basalts altered by low-temperature interaction with seawater and can be attributed to the stratigraphic position of phase 2a tuffs immediately below the glauconite datum level marking the onset of the major marine transgression.

As noted earlier, the boundary between Subunits IVb and IVc marks a major change in the depositional history of the west margin of Rockall Plateau that is also recorded at the other sites. Subunit IVb is dominated by volcanic tuffs reworked with, and interbedded with, zeolitic foraminiferal nannofossil chalk. Its base lies at or close to the NP10/11 boundary. Other remaining zones of the early and middle Eocene are present, and the top is drawn at a hiatus in the middle Eocene (NP14). Several normal polarity intervals occur in the unit, of which the lowest is Anomaly 24B. Tuffaceous, highly glauconitic mudstones define the base of the unit and lie just below the level at which epidote and amphibole disappear from the heavy mineral assemblage to be replaced by minerals derived from a basaltic terrain. The volcanic tuffs are much less abundant than in the lower unit and consist of vitric and lithic materials. The glasses are exclusively of tholeiitic type. The background sediments contrast with those of the underlying subunit. The predominant lithotype is nannofossil-foraminiferal chalk with a high zeolite and biogenic silica content. Burrows are extremely common. Scour, cross laminae, and soft sediment deformation suggest higher energy or local tectonic activity. However, there is an upward decrease in abundance of the macrofauna of gastropods, bryzoans, and in-situ bivalves consistent with the rapid increase in water depths in the range 75-200 m (Core 12-4) inferred from the benthic forams (Murray, this volume).

The overlying Subunit IVa is separated from IVb by a hiatus comprising at least all of NP15. In marked contrast, the sediments consist of biosiliceous nannofossil foraminiferal chalk, showing a complete absence of soft sediment deformation, scour, and cross-bedding. Benthic foraminiferal evidence indicates water depths of deposition of bathyal depths consistent with the absence of macrofossils. Detrital mineral grains are absent, and ash is present only in minor amounts.

Site 552 terminated in basalt at T.D. overlain by normally magnetized sediments of early NP11 age in which the glauconite horizon recorded widely at Leg 48 and 81 sites is absent (Montadert, Roberts et al., 1979; Morton, this volume). However, the expanded late early and middle Eocene section cored at this site provides fuller information on changing environmental conditions during this period of the margin's history. The basalt cored for $1.30 \mathrm{~m}$ above T.D. may represent the upper part of a submarine flow. Rapid cooling is suggested by the variation in lithology within the flow (Harrison et al., this volume), and extrusion in shallow water is postulated from the presence of a small pillow and the absence of a sharp contact with the overlying reddened shallow marine sediments. These relationships and age of sediment above the basalt suggest that the flow was a later event that post-dated the main flows of the dipping reflector sequence. Geochemical studies show that the basalt is strongly LREE-depleted in common with the other Leg 81 basalts, although Richardson et al. (this volume) note that the basalt was $\mathrm{Zr}$-rich and highly evolved.

Unit IV of Site 552 is equivalent to Units IVa and b of Site 553. The basal Subunit IVd consists of ferriginous diatomaceous claystone, normally magnetized and of NP11 age (latest NP10?) resting on the basalt. The overlying Subunit IVb consists primarily of volcanogenic sediments (minor in comparison to the pre-NP11 intervals of Site 553). The principal lithologies are vitric volcanic ash, calcareous and biosiliceous volcanic ash, and glauconitic spiculite. The volcanic glass is of tholeiitic composition. The Greenland heavy mineral association 2 is absent, and the "Rockall" association 3 of garnet, augite, aparite, and pargasitic amphiboles is dominant. The sediments show evidence of syn-depositional instability and were deposited in water depths of 75-100 m. As found at Site 533, a marked change in lithology to a predominantly pelagic section occurs in the latest early Eocene. The abundant volcanics and Rockall heavy mineral suite of underlying Subunit IVb disappear and are replaced by zeolitic mudstones, biosilieous mudstones, spiculites, porcellanites, and cherts. Water depths of deposition were not less than $700 \mathrm{~m}$.

\section{Zone II: Site $\mathbf{5 5 4}$}

Site 554 was drilled on the outer high defining the oceanward edge of the dipping reflector province. The hole terminated in basalt at T.D. A total of $82.60 \mathrm{~m}$ of interbedded basaltic lava flows, volcanogenic sandstones, and conglomerates were cored between $128.60 \mathrm{~m}$ and $209 \mathrm{~m}$ T.D. (Unit V). The top of this sequence corresponds to the reflector defining the crest of the outer high.

At least six flows may be present although recovery was poor. Flows are typically rimmed with palagonite. Submarine eruption is inferred from the presence of fragmented pillows and hyaloclastite within the breccia infilling fractures in the basalt. The basalts are petrographically uniform tholeiites and represent a highly evolved $\mathrm{Zr}$-magma type of MORB affinity (Richardson 
et al., this volume). Joron et al. (this volume) document extreme depletion of LREE's that are more typical of values found for zero-age crust.

The conglomerate consists of rounded to angular clasts of basalt, highly altered basalt, and palagonite cemented by calcite spar. Characteristic features of the sandstones and congolmerates are the lack of a clay matrix or any other terrigenous detritus, bioclastic carbonate, and sedimentary structures. The contact with the underlying basalt is sharp and suggestive of erosion. Penetration of sand into fractures in the basalt suggests eruption, erosion, and deposition possibly in a high-energy, littoral environment. No fossils were found in the conglomerate, but the sediments and basalts of the unit exhibit normal polarity with the exception of one reverse polarity measurement, possibly made on a boulder (Krumsiek and Roberts, this volume). The normal polarity of the basalts suggest formation in Anomaly-24B time and therefore that the outer high is the first oceanic crust.

The thin early Eocene interval (Unit IV) overlying the basalts consists of zeolitic tuffs and marlstones of late NP10 and NP11 age and is of normal polarity. No heavy minerals were found, in marked contrast to the section of equivalent age at Site 553. Depths of deposition indicated by benthic foraminifers range from $75-125 \mathrm{~m}$ in the lower part to $100-150 \mathrm{~m}$ in the upper. The middle Eocene (NP12-18 interval) was either not deposited or was completely removed by pre-late Eocene erosion. The late Eocene sediments are glauconite-rich foraminiferal chalks deposited in water depths of at least $700 \mathrm{~m}$.

\section{Heat-Flow Measurements}

Downhole temperature measurements were made at various depths in Leg 81 holes using the techniques described by Erickson et al. (1975). Thermal conductivity measurements were made on board using the needle probe technique described by Von Herzen and Maxwell (1959). Time constraints have not allowed full calculation of the errors and corrections in these measurements, and the preliminary shipboard data are therefore tabulated in Table 1. A full report will be published elsewhere.

The preliminary values in Table 1 compared in Table 2 with heat flows determined at nearby Sites 403 and 406 during Leg 48, together with the heat flow estimated for 50-60 m.y. by Parsons and Scalter (1977).

Table 1. Preliminary heat-flow measurements, Leg 81 .

\begin{tabular}{ccccc}
\hline Site & $\begin{array}{c}\text { No. of } \\
\text { measurements }\end{array}$ & $\begin{array}{c}\text { Temperature } \\
\text { gradient } \\
\left({ }^{\circ} \mathrm{C} \mathrm{km}-1\right)\end{array}$ & $\begin{array}{c}\text { Mean thermal } \\
\text { conductivity } \\
\left(\mathrm{W} \cdot \mathrm{m}^{-1}{ }^{\circ} \mathrm{C}^{-1}\right)\end{array}$ & $\begin{array}{c}\text { Heat flow } \\
\left(\mathrm{m} \cdot \mathrm{W} \cdot \mathrm{m}^{-2}\right) \\
\left(\mathrm{cal}^{-2} \mathrm{~m}^{-2} \cdot \mathrm{s}^{-1}\right)\end{array}$ \\
\hline 552 & 4 & 53.75 & $\begin{array}{c}1.129 \\
(12 \text { values })\end{array}$ & $\begin{array}{c}60.68 \\
(1.45)\end{array}$ \\
553 & 5 & 64.51 & $\begin{array}{c}1.319 \\
(12 \text { values })\end{array}$ & $\begin{array}{c}85.08 \\
(2.04)\end{array}$ \\
554 & 3 & 36.84 & $\begin{array}{c}0.71 \\
(21 \text { values })\end{array}$ & $\begin{array}{c}26.84 \\
1.33\end{array}$ \\
555 & 6 & 53.0 & $0.63)$ \\
$(12$ values $)$ & 71.82 \\
& 5 & & & $(1.71)$ \\
\hline
\end{tabular}

Table 2. Comparision of preliminary Leg 81 heat-flow values with those from Sites 403 and 406, plus estimated values for 50-60 m.y. crust.

\begin{tabular}{ccc}
\hline Site & $\begin{array}{c}\text { Heat flow } \\
\left(\mathrm{m} \cdot \mathrm{W} \cdot \mathrm{m}^{-2}\right)\end{array}$ & $\begin{array}{c}\text { Heat flow } \\
50-60 \text { m.y. crust }\end{array}$ \\
\hline 403 & $1.61 \pm 0.38$ & 1.46 \\
& $1.52 \pm 0.10$ & 1.46 \\
506 & $1.65 \pm 0.25$ & 1.46 \\
552 & 1.45 & 1.46 \\
554 & 2.04 & 1.46 \\
555 & 0.63 & 1.46 \\
\hline
\end{tabular}

The uncorrected values all lie close to the heat-flow value expected for oceanic crust of this age, but there is no indication of a systematic change in magnitude that might be related to structural position on the margin or distance from Anomaly 24B. For example, the lowest heat-flow value recorded on the outer high (partly overlapped by Anomaly 24B) is less than half the value predicted by Parsons and Sclater (1977), and the highest value is recorded at Site 555, the most distant from Anomaly 24B.

Heat-flow measurements in the adjacent Iceland Basin have been reported by Langseth and Zielinski (1974) and Bram (1980). Their results show a uniform and very high heat flow in the distance range of $170-340 \mathrm{~km}$ from the ridge crest of about $100 \mathrm{~m} \cdot \mathrm{W} \cdot \mathrm{m}^{-2}$; that is nearly twice the average heat flow west of the ridge and about $30 \%$ over the computed heat flow. However, the values observed on the west margin of Rockall Plateau lie close to those predicted by the cooling plate model. The difference may be attributed to a westward and nonlinear increase in temperature at the lower plate boundary, possibly related to proximity to the Iceland hotspot.

\section{Subsidence History}

One of the more generally held concepts of passive margin evolution considers that subsidence and cooling of the margin is initiated at the onset of spreading after heating and stretching during the rifting phase. The amount of subsidence of any part of the margin is dependent on the quantity of stretching and therefore on the original thickness and temperature of the lithosphere. In general, subsidence can be expected to decrease away from the continent/ocean boundary, but a general exponential subsidence law can be expected to describe the subsidence observed at any point on the margin (McKenzie, 1978; Watts and Ryan, 1976; Montadert, Roberts et al., 1979).

Figure 11 summarizes the paleobathymetric data derived from studies of benthic forams for the sites on Rockall Plateau (Murray, this volume). Other subsidence data used in the following discussion are from Montadert, Roberts, et al. (1979).

In the case of Sites 552, 553, 554, 403, 404, and 555, the data (Fig. 11) show that all lay in closely comparable water depths at the onset of rapid regional subsidence 


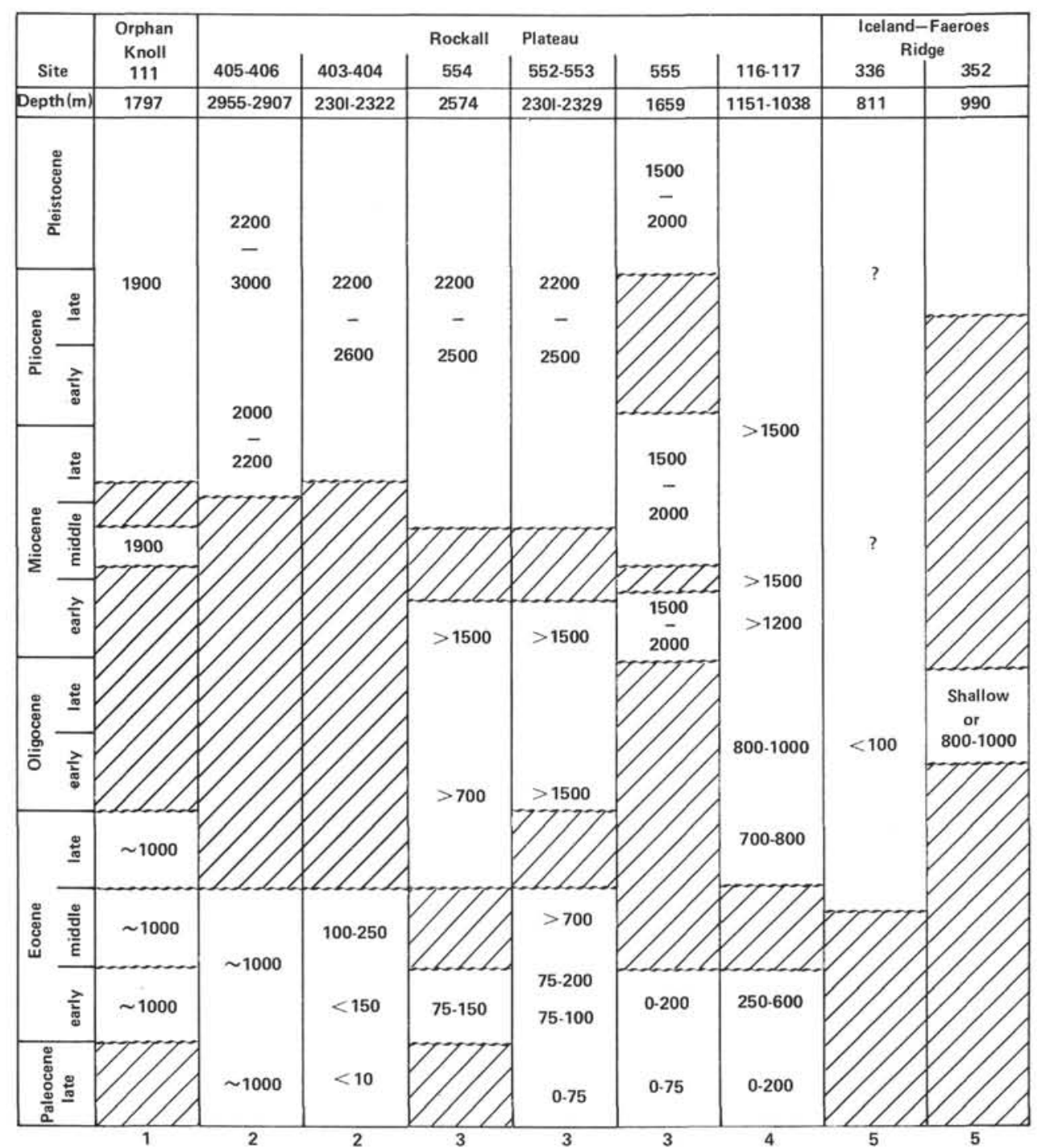

Figure 11. Summary of paleobathymetric data from benthic forams, sites from Legs 12, 48, and 81 . (Murray, this volume.)

just prior to Anomaly 24B. The subsidence curves fall into two groups. Curves for Sites 552, 553, and 554 lie between a $\beta$ value of 3 and the empirical curve for the oceanic lithosphere. It is important to note that, for values of $\beta$ from $4-\infty$, differences in the form of the subsidence curve are small and lie well within the observational data used to constrain the curves for the Leg 81 sites. In these cases, distinction between stretched continental lithosphere and oceanic lithosphere cannot be uniquely made from the form of the curves. This is not the case for Sites 116 and 117 where independent geophysical evidence of continental crust (Scrutton, 1972; Roberts, 1975) provides the necessary constraint. Even at these sites, $\beta$-factors of c. 3 are indicated by the form of the curve.

As noted by Murray (this volume), the fragmentary late Paleogene and early Neogene record and the uncertain ecological requirements of some Paleogene taxa all make precise assignment of depths to environments dif- ficult. Nonetheless the overall magnitude of the subsidence indicates a very wide area of large stretching extending from Anomaly 24B in the west to the edge of Rockall Bank in the east-a distance of about 200-300 $\mathrm{km}$. This distance is approximately the same as the width of the margin in the Bay of Biscay between the unstretched crust of the shelf and the continent/ocean transition (Avedik et al., 1982). It is interesting in this context that Bullard et al. (1965) found it necessary to close Hatton Bank and Rockall Bank together to achieve a satisfactory total closure of the North Atlantic. The reference made here to a wide zone of stretching is consistent with their earlier observation.

\section{GEOLOGICAL HISTORY OF THE WEST MARGIN OF ROCKALL PLATEAU}

The rift history of the west margin of Rockall Plateau is recorded in two sedimentary sequences bounded by unconformities identified as prominent reflectors that 
are observed on seismic profiles throughout the area (Fig. 12).

Sequence 3:

$\mathrm{m}$. Eocene-Recent Pelagic/hemipelagic oozes/chalks/clays -Reflector 1-( $\equiv$ R4 of Roberts (1975)

Sequence 2:

late Paleocene-1. Eocene-predominantly volcaniclastics

-Reflector 2-

Sequence 1:

late Paleocene dipping reflectors-basalts and interbedded tuffs/sediments

\section{Sequence 1: Late Paleocene}

The late Paleocene basalts penetrated at the Leg 81 sites on Rockall Plateau form part of a now fragmented and deeply subsided volcanic province that includes East Greenland and the Faeroes (Roberts et al., this volume).

Throughout the region, the Paleocene sequence located landward of Anomaly 24B lies in three characteristic structural zones.

The flat-lying lavas of Zone I penetrated at Site 555 and lying near outcrop on Edoras Bank probably extend eastward over much of Rockall Plateau to Site 117 (Laughton, Berggren et al., 1972). Available refraction data (Gaskell, Hill, and Shallow, 1958) suggest considerable variation in thickness of the lavas. The nature of the underlying basement is not directly known, but its presence is inferred from gravity models (Scrutton, 1972; Roberts and Ginzberg, 1984) and indirectly shown by the age and nature of heavy minerals found in sediments interbedded with the basalts (Duddy et al., this volume; Morton, this volume); the base of the sequence may be represented on Edoras Bank by a strong westerly dipping event beneath the flat-lying reflectors. Although its westward extent cannot be determined from the seismic data, Roberts and Ginzberg (1984) suggest that it may continue beneath the dipping reflectors as far as the outer high.

Geochemical studies of the basalts show that they are depleted tholeiites of MORB affinity and share many common features with basalts from the Faeroes and elsewhere in the region (Richardson et al. and Joron et al., this volume). As noted by Macintyre and Hamilton (this volume) the absence of isotopic evidence to the contrary cannot be used to infer the absence of continental crust. Indeed, isotopic evidence from the Faeroes basalts for the well-established underlying microcontinent remained lacking for many years.

It should also be noted that the Leg 81 sites only penetrated the uppermost part of a 6-km-thick basalt pile. Comparison with East Greenland and paleomagnetic studies (Roberts et al., and Krumsiek and Roberts, this volume) suggest that the entire basalt pile erupted during the short reverse polarity interval between Anomaly 24 and 25 . The data from Sites 553, 555, and 117 suggest contemporaneous subaerial or shallow marine flood basalt eruption over a wide area at or close to sea level. A very rapid rate of basalt eruption is shown by secular variation cycles preserved in the paleomagnetic record (Krumsiek and Roberts, this volume). The rate of basalt accumulation was sufficient to keep pace with tectonic subsidence due to rifting and to maintain the surface of the pile at or close to sea level. Minor variations in accumulation rate and/or subsidence allowed transgression or regression and the influx of continental detritus and reworked volcaniclastics. Much of the laterial variation in reflection character and continuity within the dipping reflector sequence may be a consequence of the relative proportions of sediment (marine, volcaniclastic, soils) and lava as well as the natural variation in physical properties, thickness, and persistence of individual flows and packages of flows that partly cause the reflectors.

The overlying late Paleocene-early Eocene sequence records an almost complete cut-off in eruption of basalt flows and a change to pyroclastic volcanism recorded widely throughout the North Atlantic, Norwegian Sea, and North Sea (Roberts et al., this volume; Morton and Keene, this volume). A local origin for the pyroclastic volcanism is suggested by the coarse grain size of the tephras. Strong fractionation of the source magmas is suggested by the presence of alkali basalts, tholeiites, and andesites although only tholeiites occur in the later part. The occurrence of potash metasomatism (celadonite) and the pyroclastic volcanism suggest strong watermagma interaction. Heavy minerals occurring in the interbedded sediments have a Southeast Greenland provenance. It is important to note that, as in the preceding

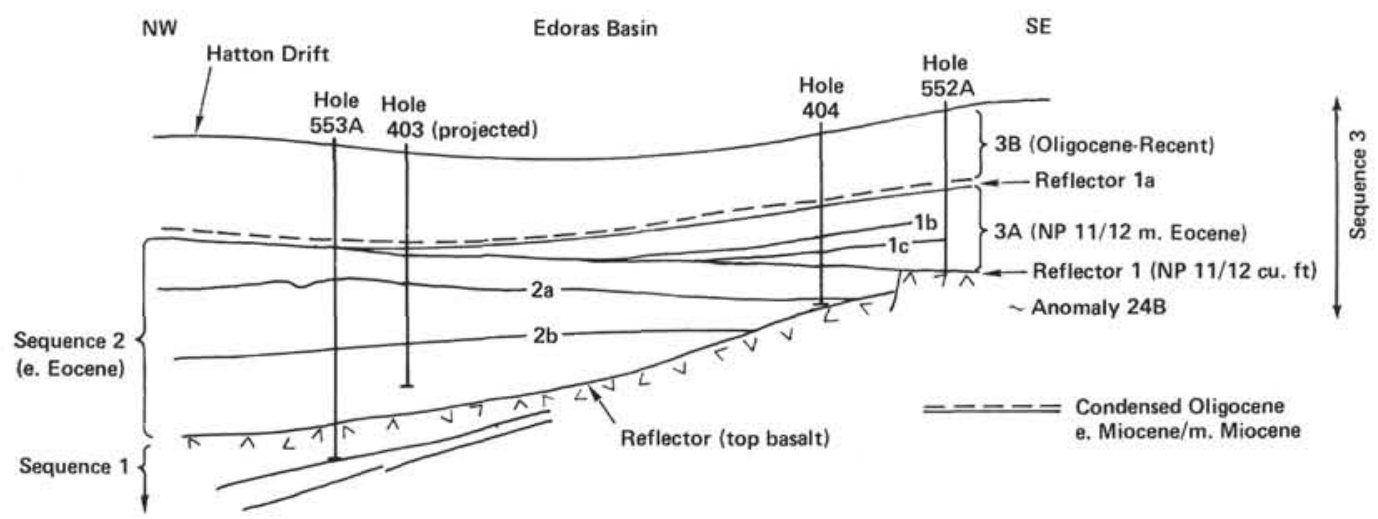

Figure 12. Principal depositional sequences, southwest Rockall Plateau (not to scale). 
phase, sedimentation evidently kept pace with subsidence (we do not have sufficient biostratigraphic resolution to judge whether the sedimentation rate was the same as the lava eruption rate or whether subsidence had slowed). However, just prior to Anomaly-24B increased subsidence is shown by the regional transgression marked by the glauconite datum in coincidence with a cut off in the supply of Greenland heavy minerals and the abrupt termination of pyroclastic volcanism.

The important differences between Sequence 1 and Sequence 2 can be more fully understood by considering the relationship of these sequences to the outer high. Reflector 2, the top of the dipping reflector sequence, can be confidently followed northwestward to about 5 $\mathrm{km}$ east of the outer high. In the overlying Sequence 2, to the northwest of this point, a very similar and strong reflector appears above the basalts and passes laterally to the southeast into the sediments of Sequence 2 (Fig. 13). Two succeeding strong reflectors exhibit the same lateral passage into this sequence at the level of the main tuff horizons and are also characterized by diffractions at their terminations. An origin by upthrow of the underlying, dipping reflectors of Sequence 1 has to be excluded because they show no displacement. The probable explanation is that the volcaniclastics cored at Site 553 pass laterally and northwestward into a series of interbedded lavas and tuffs. The change in type of volcanism to explosive may therefore be due to westward migration of the linear(?) volcanic axis into the deeper or deepening rift axis.

In addition, two other important changes occur in the vicinity of the outer high. The repeated upward succession of possible lava flows is absent, and faulting affects the whole section to a level just above the highest lava flow. The age of this faulting may decrease towards the outer high, indicating westward migration with time. The age of the faulting is not precisely known but it cannot be younger than Reflector 1 , which arises from the lithologic contrast between Subunits IVb and IVe just below sediments of Anomaly 24B age. The direction of downthrow of the faults is variable but downthrow to the east predominates toward the outer high as the age of the faulting decreases. The presence of dipping reflectors within the fault blocks and the sense of motion along the blocks suggest uplift and inversion of the western part of the dipping reflector sequence. This conclusion is also supported by the development of eastward prograding clinoforms that indicate erosion of a more elevated area to the west.

Evidence for a shallow marine or even subaerial position for the outer high is shown by the presence of beach sediments at Site 554 substantially below the crest of the high. Further evidence is given by the magnetic anisotropy study of Leg 48 sediments (Hailwood and Sayre, 1979) and by heavy mineral studies (Morton, this volume). These studies indicate a westerly source for sediments containing East Greenland heavy minerals and therefore the absence of an effective barrier that would be provided by an outer high. The cut-off in "Greenland" heavy minerals (Morton, this volume) may be due to formation of the outer high in Anomaly 24B time. As shown earlier in this chapter, the normal polarity and partial overlap of the high by Anomaly 24B, and the MORB character of the basalts comprising the high, together suggest the reasonable possibility that the high may represent the first oceanic crust formed early in Anomaly 24B time following progressive uplift of the basin axis. As noted earlier, the paleodepth data for the high strongly suggests it was subaerial.

The restored sections (Fig. 16) summarize the history of the basin in late Paleocene-early Eocene time leading up to the formation of the outer high. It is important to note that the uplift was accompanied at least in its early stages by westward migration of volcanic activity; an alternative origin wholly by localized accumulation of basalts or in association with the uplift is therefore equally possible and might account for the variable development of the outer high along strike (Montadert, Roberts et al., 1979; Mutter, et al., 1982). However, the ubiquitous occurrence of Greenland heavy minerals is not easily reconciled with the presence of an axial and linear volcanic pile which would have acted as an effective barrier.

The evidence pointing to subaerial exposure of the outer high carries several implications for the genesis and history of the oceanic crust of Zone IV. The geological cross section demonstrates that the inner flank of the outer high and adjoining oceanic basement of Anomaly 24A and B age (Roberts et al., 1979) lie at the same depth. Assuming that the crust has remained coupled between the two sites, this indicates that the adjacent oceanic crust formed at about the same depth as the outer high-i.e., in depths probably less than $100 \mathrm{~m}$. Farther north the oceanic basement is shallower, and from this argument would have been subaerial. Subaerial to shallow marine accretion of the oceanic crust would have resulted in contemporaneous deposition of lavas and sediments as well as post-24B pyroclastic volcanism. While an analogy might be drawn with Iceland, the thin crust west of the high (Roberts and Ginzburg, 1984) cautions against this.

A more apt analogy is perhaps provided by the Danakil depression or the Gulf of Tadjura, where subaerial or shallow marine oceanic crust is forming in close proximity to the continent (Roberts and Whitmarsh, 1968). This model may explain the impersistent subbasement reflectors observed on seismic profiles in the adjacent oceanic crust whose western limit is diachronous (Roberts et al., 1979). The diachroneity may reflect subsidence of the ridge crest (cf. Reykjanes Ridge) to more normal depths. In this context, it is noteworthy that the observed depth of the oceanic crust (c. $2700 \mathrm{~m}$ ) is still much less that the $5000 \mathrm{~m}$ depth predicted by the $\mathrm{Le} \mathrm{Pi}$ chon et al. (1976) curve. However, use of the present depth of $1000-1500 \mathrm{~m}$ on the Reykjanes Ridge axis rather than the average $2500 \mathrm{~m}$ given by Le Pichon et al. (1976) give a reasonable fit to the observed depth of the crust near Site 554 and indeed the depth may have been even shallower. A likely cause for the anomalously shallow depth of the first oceanic crust is that the lithosphere may have been substantially hotter (and or thinner?) than the more typical oceanic lithosphere to the south (see Haigh, 1972). The proposed existence of hot- 


\begin{tabular}{|c|c|c|c|c|c|c|c|c|c|c|c|c|c|c|}
\hline NW & & & & & $\begin{array}{l}\text { LINE } \\
\text { SP }\end{array}$ & $\begin{array}{l}76-6 \\
3\end{array}$ & & $\begin{array}{l}\text { E IPOD7 } \\
\text { P } 13600\end{array}$ & & & & & & SE \\
\hline 1600816000 & $\stackrel{15950}{\perp}$ & $\underset{15900}{\perp}$ & $\begin{array}{c}15850 \\
\perp\end{array}$ & 15800 & 15750 & 15700 & 15650 & 15600 & 15550 & $\begin{array}{c}15500 \\
\perp\end{array}$ & 15450 & 15400 & 15350 & $15300 \mathrm{SP}^{\prime} \mathrm{s}$ \\
\hline
\end{tabular}

2.0

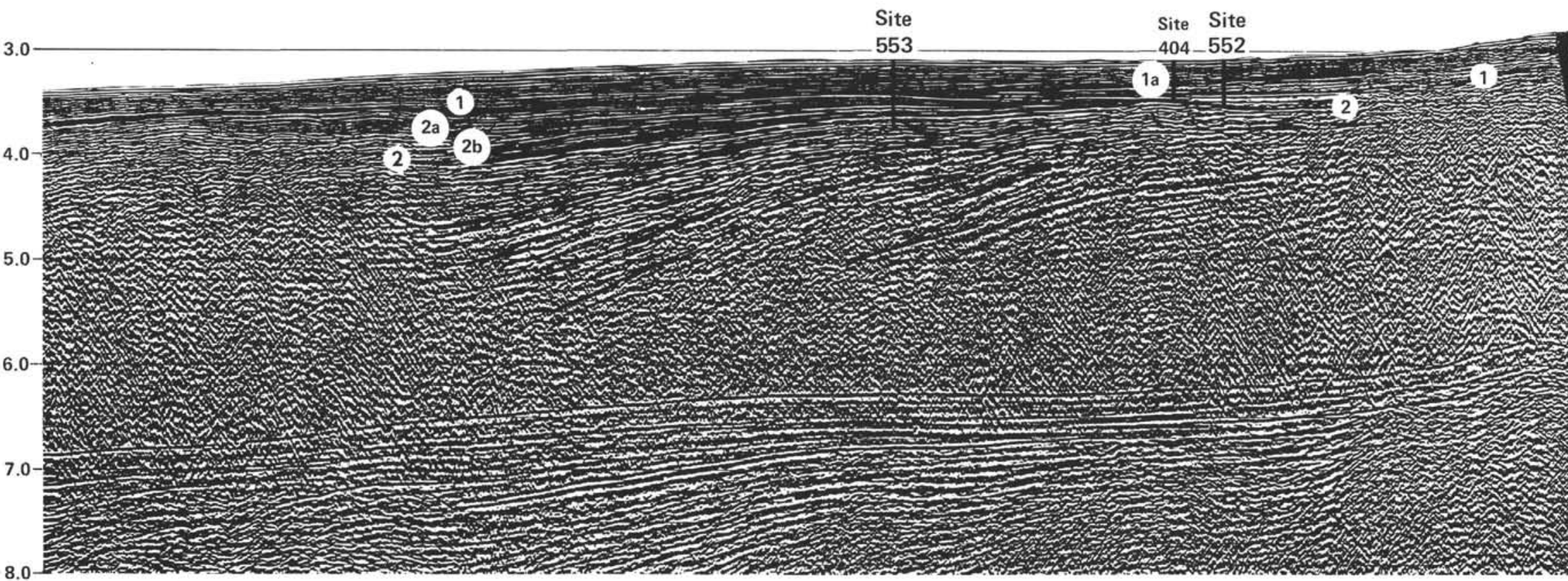

Figure 13. Seismic profile between Site 553 and the outer high. Note the development of eastward prograding clinoforms in sequence 2. Antithetic faulting becomes more prominent toward the outer high. Line is located in Figure 6. 
ter lithosphere may have caused the voluminous volcanism observed throughout the conjugate margins of the area (Roberts et al., this volume).

\section{Analogies with East Greenland}

The almost ubiquitous occurrence of dipping reflectors on the conjugate margins of the northern Atlantic and Norwegian Sea has obvious regional importance in understanding the history of rifting between Greenland and Northwestern Europe. On the conjugate East Greenland margin, comparable reflectors occur the length of the margin from Cap Farvel in the south to Scoresby Sund in the north (Figs. 13, 15, 16).

Consideration of the regional distribution of the dipping reflectors in relation to Anomaly 24B shows that the basalts of the Blosseville Kyst lie directly along strike with the dipping reflectors. Further, Larsen (pers. comm) has shown from aeromagnetic data that Anomaly 24B lies at the coast or just offshore. The clear equivalence of the Greenland basalts with those drilled on Leg 81 is discussed in detail elsewhere in this volume (Roberts, et al.). However, the significant point is that the Blosseville Kyst basalts may represent the onshore equivalent of the dipping reflectors offshore, exposed by the fortuitous accident of Oligocene uplift (Brooks, 1980). In addition, the thin marine sequence exposed at the top of the basalt pile is stratigraphically equivalent to part of Sequence 2 overlying the dipping reflector sequence (Roberts et al., this volume).

Figure 15 compares the classical geological cross section of East Greenland (Wager, 1934) with a section at a comparable scale across Rockall. In part B of Figure 15, East Greenland has been restored to sea level to allow for post-Eocene uplift and the fact that the terminal eruptions took place at or close to sea level (Soper et al., 1976). The same procedure in reverse has been applied to the section across west Rockall. Although no adjustment has been made for tilt during subsequent or uplift, the similarity is compelling and argues for a comparable mehanism of eruption and accumulation in both areas.

Use of the fuller geological information from East Greenland provides two important constraints on possible mechanisms (Fig. 17). Firstly, Mesozoic and older rocks underly the basalts on the south Scoresby Sund area only a few km west of the dyke swarm and Anomaly 24B (Larsen, pers. comm). Secondly the dyke swarm is located close to the coast and penetrates to high levels in the Greenland basalts here considered to be the equivalent of the dipping reflectors (Nielsen and Brooks, 1981). The first observation suggests that continental crust at least in part underlies the dipping reflectors, and the second that intense and localized dyke intrusion was associated with the terminal phases of development of the margin at or close to Anomaly 24B. In addition important new observations by Nielsen and Brooks (1981) show landward dipping antithetic faults that postdate the dyke intrusion (cf. earlier discussion) and resulted in the development of the coastal flexure.

\section{Evolution of Volcanic Margins-The Rockall Model}

A hypothesis for the development of volcanic margins characterized by dipping reflectors that embodies the Leg 81 results and the geology of East Greenland is shown in Figure 18. The prebasalt geology of East Greenland provides the basis for the speculative early stages.

Stage A. Thin late Cretaceous and early Paleocene sediments were deposited in an epicontinental basin on pre-Cambrian basement.

Stage B. Lava flows were extruded onto this surface in the early part of the Anomaly $24 \mathrm{~B} / 25$ interval (Roberts et al., this volume).

Stages $C$ and $D$. Voluminous and rapid eruption took place in a time interval no longer than that represented by Zone NP9 and possibly a good deal less. Contemporaneous stretching accompanied eruption of the lavas, while the rapid accumulation of the lavas loaded the crust, adding to the tectonic subsidence produced by extension. Episodicity in space and time is shown by the stratigraphy of the Greenland lava pile (Soper et al., 1976). Fissure and explosive eruptions taking place over the wide area of the volcanic province (Roberts et al., this volume), with periodic influxes of sediment associated with episodic transgression and regression caused by the interplay of subsidence and lava accumulation rate, may account for lateral variations in reflection character.

Stage E. Towards the end of this phase, volcanism migrated westward and became partly submarine, resulting in a widespread and important phase of pyroclastic volcanism recorded throughout the North Atlantic area.

Stage $F$. Uplift of the central part of the rift valley took place, elevating it above sea level and so forming the outer high and the antithetic series of faults. This event may be related to the major intrusion phase (cf. Nielsen and Brooks, 1981), heralding the spreading phase by penetration of the hot mantle into the lower crust.

Stage $G$. Spreading began with the formation of the partly subaerial outer high forming the first ocean crust early in Anomaly 24B time.

Stage $H$. Spreading continued in the young ocean ba$\sin$ in depths probably less than $100 \mathrm{~m}$. Contemporaneous deposition of volcaniclastics and fissure eruptions in this environment may account for the impersistent reflectors observed in the young ocean crust. Differential thermal subsidence related to the amount of stretching during the rifting phase has resulted in the present topographic relief of the Rockall Plateau.

\section{Oceanic or Continental?}

Mutter et al. (1982) have proposed that the dipping reflectors are formed by some kind of subaerial spreading, possibly akin to that observed in Iceland (Fig. 19). The results of the Leg neither prove or disprove that the dipping reflectors are underlain by continental or oceanic crust, but provide data and in turn constraints on reasonable models for the formation of this type of margin. Detailed geophysical studies of deep crustal structure allied to a deep drilling program are an essential next step; but the results from Greenland and Rockall do point to some obvious difficulties with the model presented here as well as those of Mutter et al., (1982) for the Norwegian Sea and Montadert et al. for the Bay of Biscay. Comparison with the Bay of Biscay clearly demonstrates that the Rockall margin differs in almost 


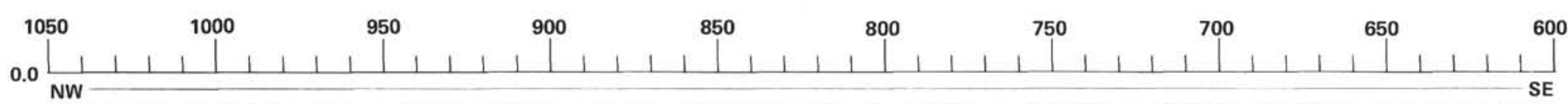

NW

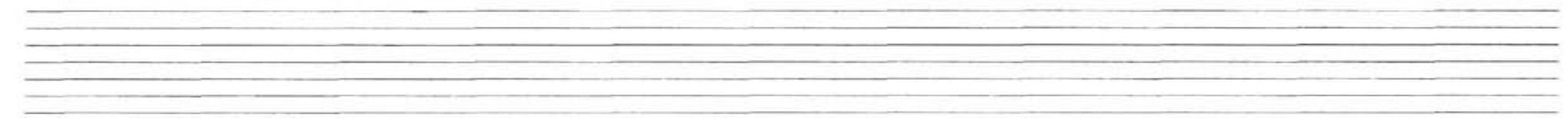

1.0

.0

2.0

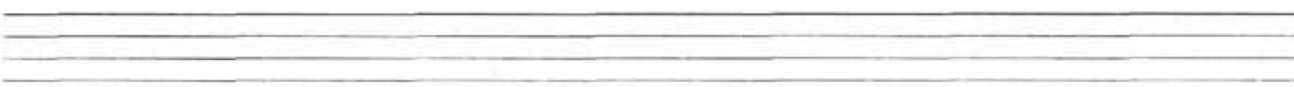

3.0
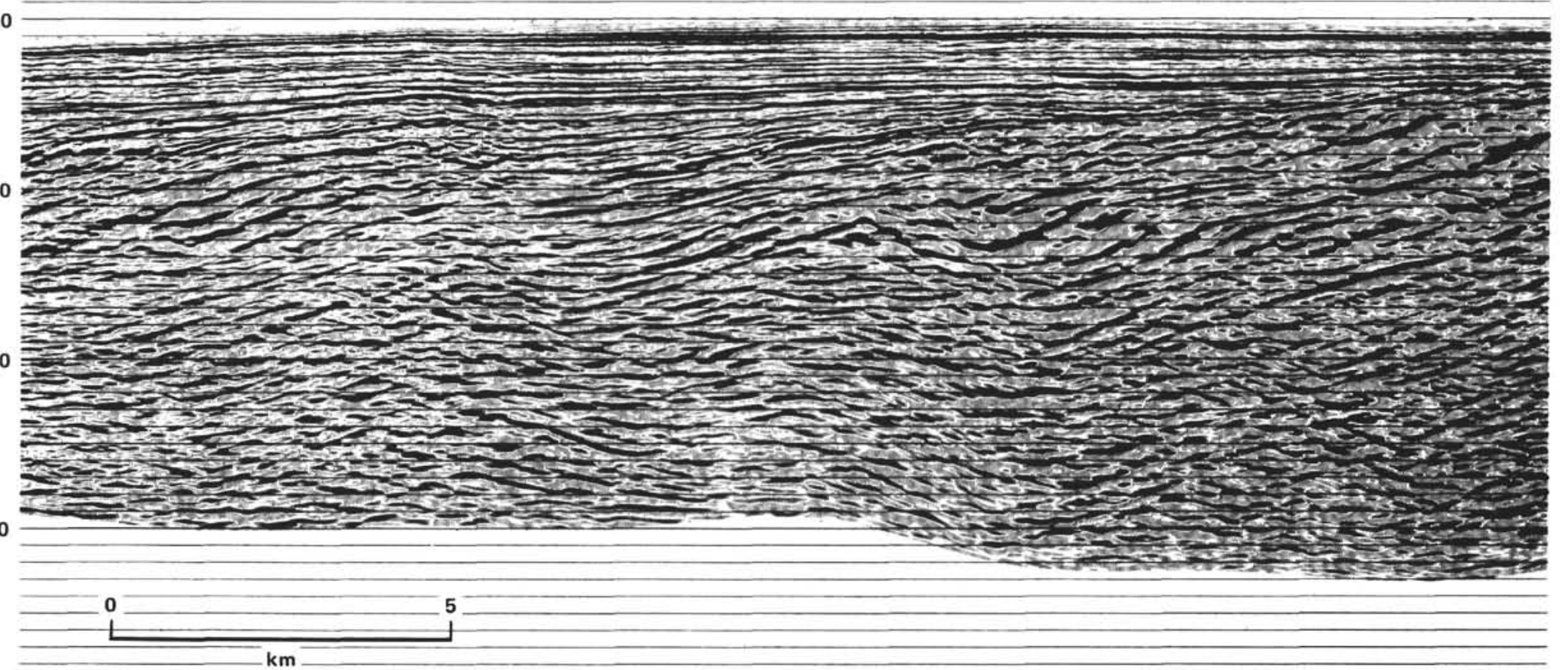

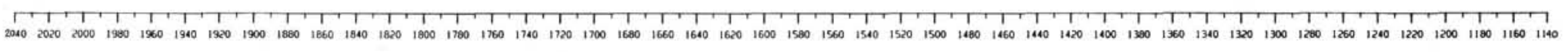
Figure 14. Depth migrated part of regional seismic line shown in Figure 5. Depth in km. 

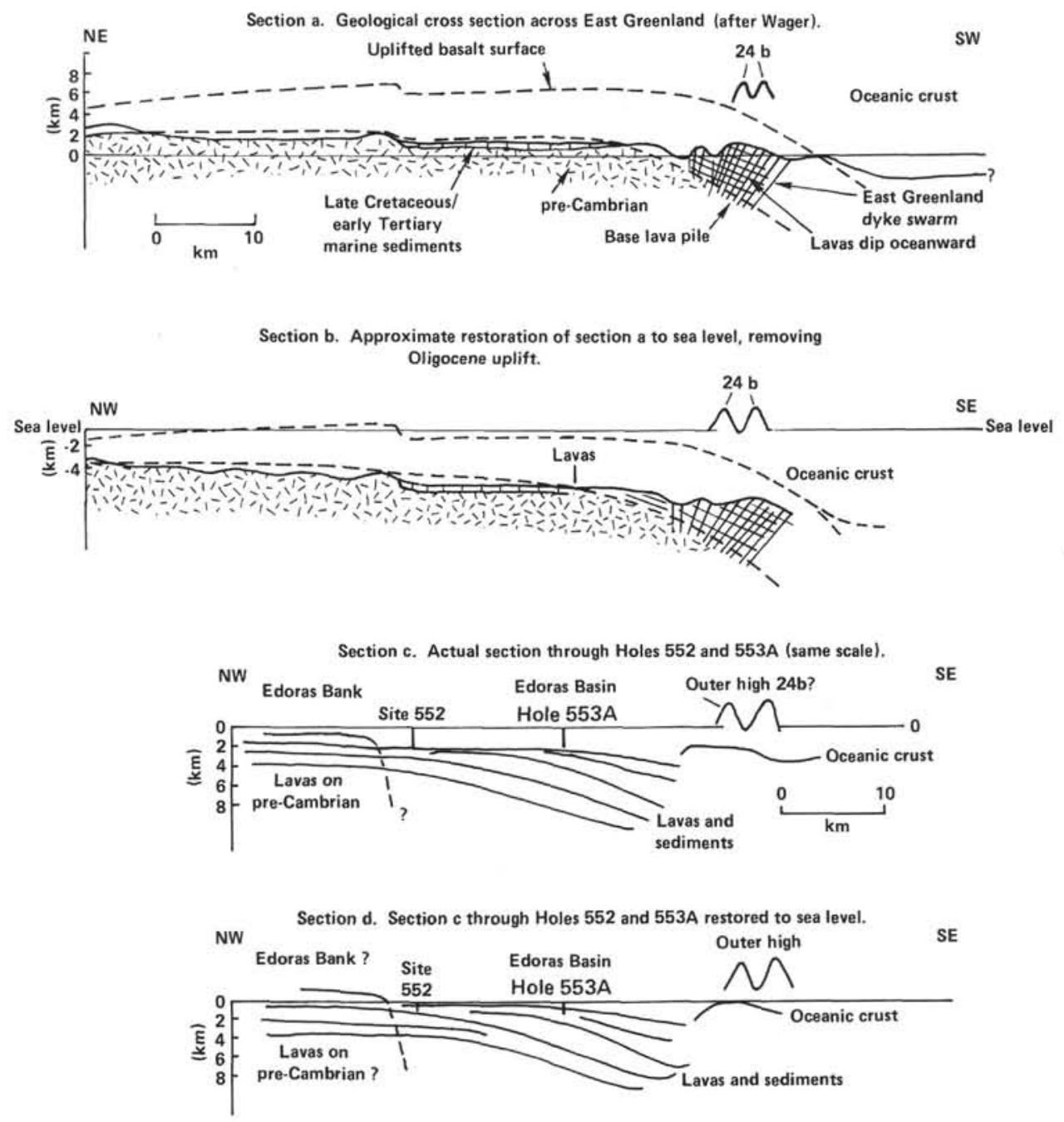

Figure 15. Palinspastic sections based on seismic line shown in Figure 13 and results from Sites 553 and 554.

all respects: tilted blocks are absent, volcanism is voluminous, and rifting was effectively instantaneous in geological time.

The more serious problems lie in defining cause and process in terms of the stretching of the lithosphere and its consequence in the development of the "dipping reflector" margin and the position of the continent/ocean transition or boundary. It is the latter that bears on cause, process, and the differences between this model and that of Mutter et al. (1982). There can be no dispute that dipping reflectors do occur in undisputed oceanic crustal settings (e.g., Kolbeinsey Ridge) but it is not a necessary consequence that dipping reflectors will always be indicative of oceanic crust. A more apposite statement is that they represent the result of a particular process that may occur in both oceanic and continental settings in response to anomalous thermal behavior in the lithosphere.

A necessary consequence of the Mutter model is that the lowest dipping reflector is fed by a dyke representing the first oceanic crust and therefore that the continent/ ocean transition or boundary will lie well landward of Anomaly 24B. This is a testable prediction that is clear- ly not met in the Blosseville Kyst area of East Greenland where the main dykes are concentrated in an area close to the coast and near Anomaly 24B and the lavas are underlain by continental crust. Futhermore, the dipping reflectors occur both entirely landward and partly overlapping Anomaly 24B is various parts of the Norwegian Sea. Roberts and Ginzburg, admittedly from non-unique gravity modelling, have argued that stretched continental crust is present beneath the dipping reflectors.

A possible compromise hypothesis is sketched in Figure 19. In this model, very rapid heating of the lithosphere is invoked as a cause of thermal weakening and in consequence rapid stretching. Accompanying dyke intrusion which feeds the flows throughout the stretching area increases in intensity in time towards the incipient spreading axis. Dyke intrusion proceeds to progressively higher levels through continental crust into the basalt pile leading to uplift (the outer high) and, at $100 \%$ intensity, the formation of the first oceanic crust (cf. Vierbuchen et al., 1983). In this case, the continent/ocean transition is gradual sensu lato rather than narrow as in the Bay of Biscay. We note that this model also embodies the requirement of Palmason's (1980) theoretical model that 


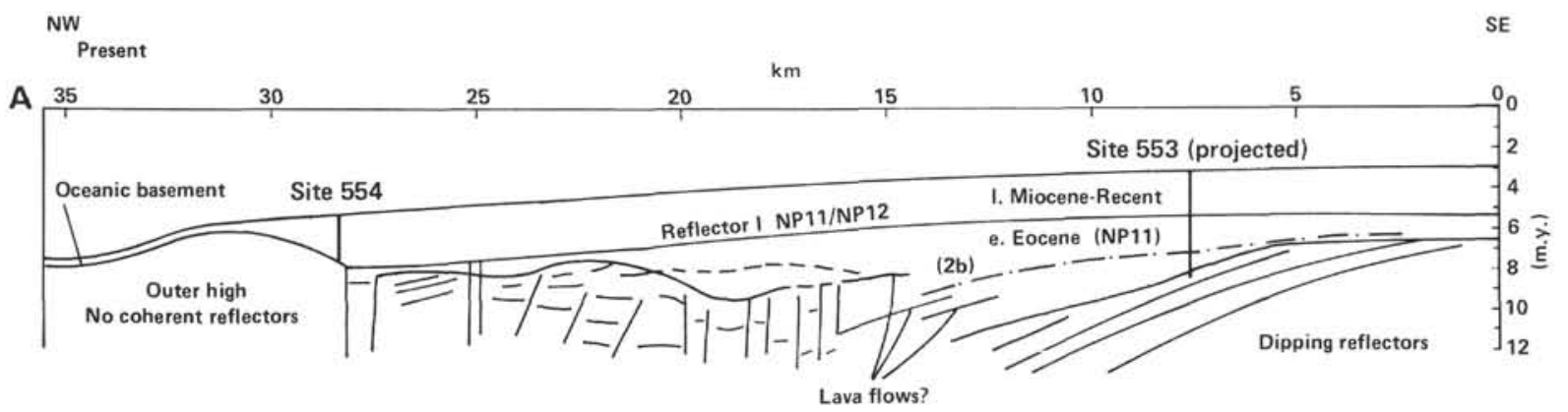

Reflector 2
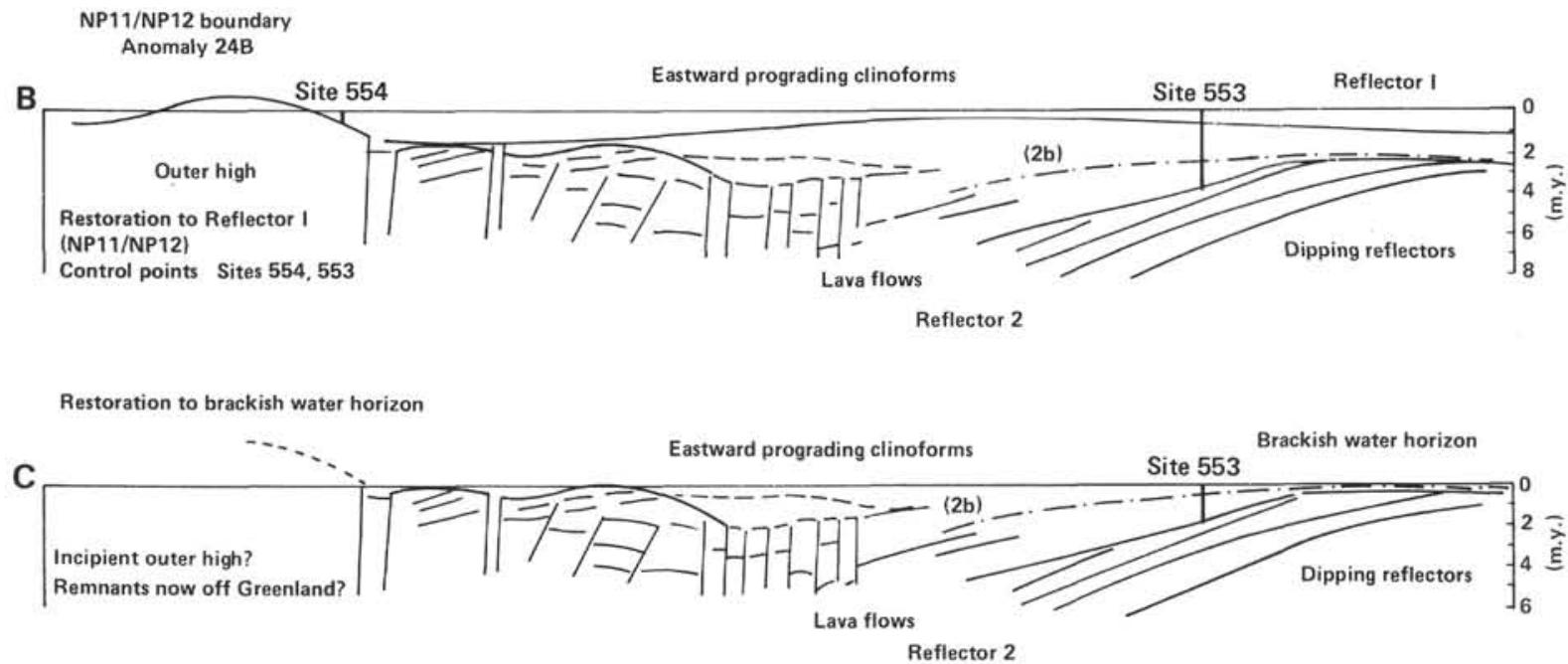

Figure 16. Distribution of dipping reflectors off East Greenland (Roberts, unpubl., Larsen, in press).

the outflow extent of the lavas equals or exceeds the width of the injection zone.

\section{ACKNOWLEDGMENTS}

D. G. Roberts wishes to thank the Department of Energy and the Natural Environment Research Council for supporting his involvement with J. Murray and A. Morton in Leg 81. British Petroleum is thanked for help in the preparation of this chapter and in the processing of seismic data. Discussions with shipboard colleagues were helpful as were the comments and help given by the Passive Margin Panel. John Mutter, Hans Christian Larsen, and C. Uruski contributed constructive discussion and dialogue on an as yet unresolved but fundamental problem of margin geology.

\section{REFERENCES}

Avedik, F., Camus, A. L., Ginzburg, A., Montadert, L., Roberts, D. G., and Whitmarsh, R. B., 1982. A seismic refraction and reflection study of the continent-ocean transition beneath the North Biscay margin. Phil. Trans. R. Soc. Lond., Series A, 305:5-25.

Beziat, D., 1983. Etude petrologique et geochimique des ophites des Pyrenées; implications geodynamiques [These de $3^{\circ}$ cycle]. Université de Toulouse, France.

Bram, K., 1980. New heat-flow observations on the Reykjanes Ridge. J. Geophys., 47:86-90.

Brooks, C. K., 1980. Episodic volcanism, epeirogenesis and the formation of the North Atlantic ocean. Palaeogeog. Palaeoclim. Palaeoecol., 30:229-242.

Bullard, E. C., Everett, J. E., and Smith, A. G., 1965. The fit of the continents around the Atlantic. Phil. Trans. R. Soc. Lond., Series A, 258:41-51.

Erickson, A. J., et al., 1975. Geothermal measurements in deep-sea drill holes. J. Geophys. Res., 80:2515-2528.
Ewing, M., and Ewing, J., 1958. Seismic refraction measurements in the Atlantic Ocean basins, in the Mediterranean Sea, on the MidAtlantic Ridge and in the Norwegian Sea. Geol. Soc. Am. Bull., 70:291-318

Featherstone, P. S., Bott, M. H. P., and Peacock, J. H., 1977. Structure of the continental margin of southern Greenland. Geophys. J., 48:15-27.

Gaskell, T. F., Hill, M. N., and Swallow, J. C., 1958. Seismic refraction measurements made by H.M.S. Challenger in the Atlantic, Pacific and Indian Oceans, and the Mediterranean Sea 1950-53. Phil. Trans. R. Soc. London, 251:23-83.

Gerrard, I., and Smith, G. C., 1983. Post Palaeozoic succession and structure of the South Western African continental margin. Mem. Am. Assoc. Pet. Geol., 34:49-76.

Graciansky, P. C., and Poag, W., in press. Geological history of Goban Spur. In de Graciansky, P. C., Poag, W. et al., Init. Repts. DSDP, 80: Washington (U.S. Govt. Printing Office).

Hagevang, T., Eldholm, O., and Aalstad, I., 1982. Pre-23 magnetic anomalies between Jan Mayen and Greenland-Senja fracture zones in the Norwegian Sea. Mar. Geophys. Res., 5(4):345-364.

Haigh, B. I. R., 1973. North Atlantic oceanic topography and lateral variations in the upper mantle. Geophys. J., 33:405-420.

Hailwood, E. A., and Sayre, W. O., 1979. Magnetic anisotrophy and sediment transport directions in North Atlantic Early Cretaceous black shales and Eocene mudstones cored on DSDP Leg 48. In Montadert, L., Roberts, D. G., et al., Init. Repts. DSDP, 48: Washington (U.S. Govt. Printing Office), 909-917.

Hinz, K., 1981. A hypothesis on terrestrial catastrophes. Wedges of oceanward dipping layers beneath passive continental margins. Geologisches Jahrb., E(22):3-28.

Hinz, K., and Weber, J., 1976. Zum geologischen Augbau des Norwegischen Kontinental randes und der Barents Sea nach reflections seismischen Messungen. Erdöl und Kohle, Erdgas. Petrochemie, 75/76:3-29. 


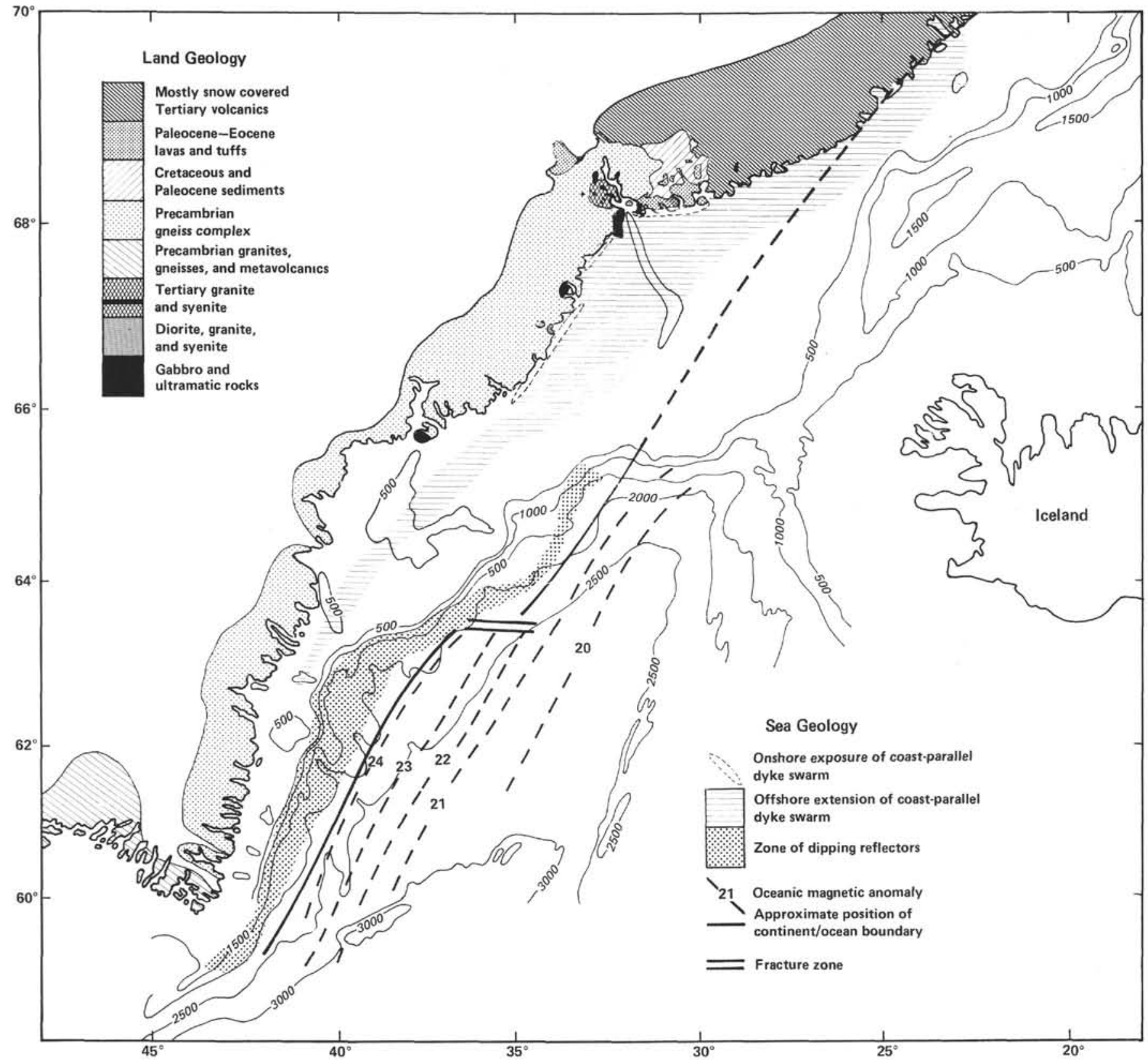

Figure 17. Comparison of East Greenland marginal flexure development with southwest Rockall Plateau. 
stage

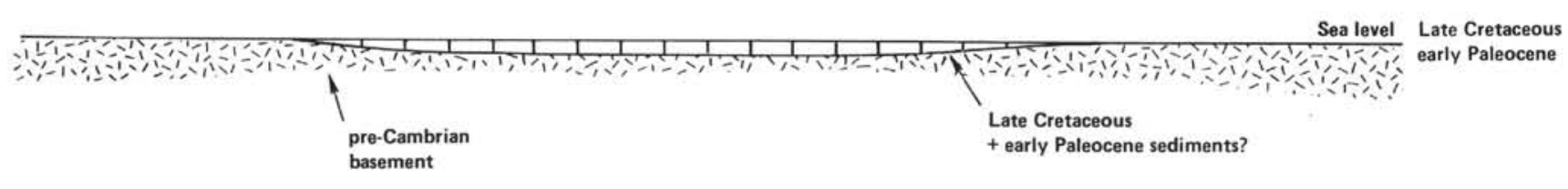

Sea level late Paleocene (NP8)

Stage B

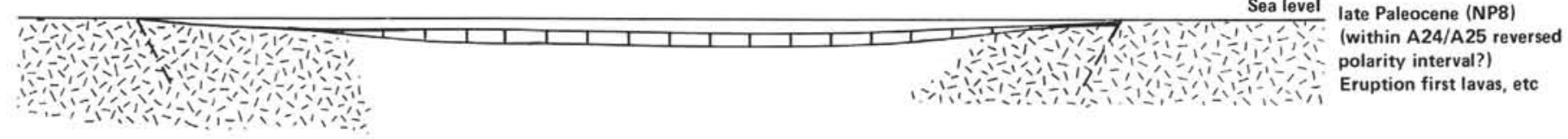

Stage C

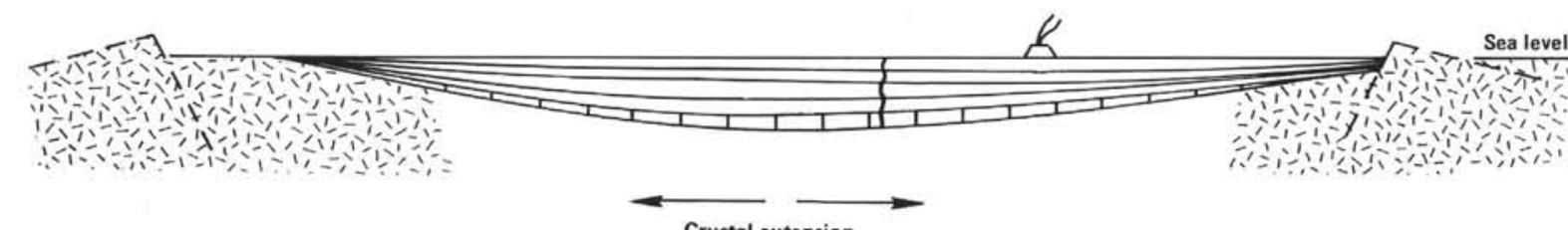

Crustal extension

Rapid and voluminous

olcanism in interval

of order of $100-500$ k.y.?

Contemporaneous

subsidence in response

Stage $\mathrm{D}$

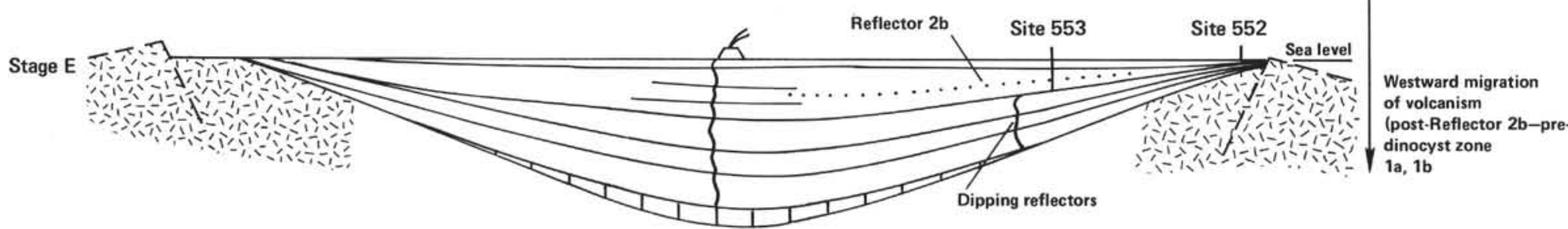

$\stackrel{\text { Crustal extension }}{\longrightarrow}$ Rising mantle diapir 


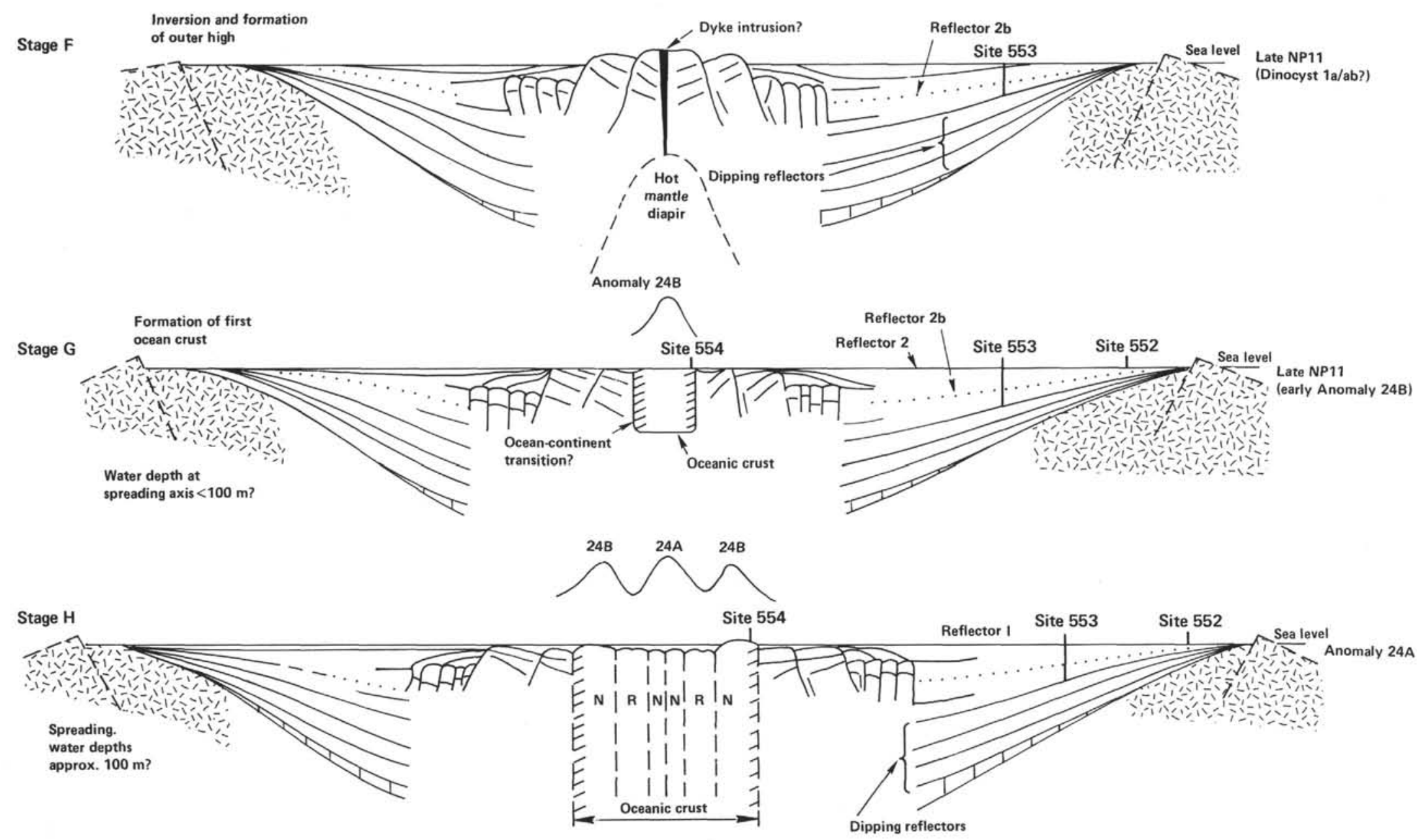

Figure 18. Hypothetical model for the structural and stratigraphic development of southwest Rockall Plateau (not to scale). 


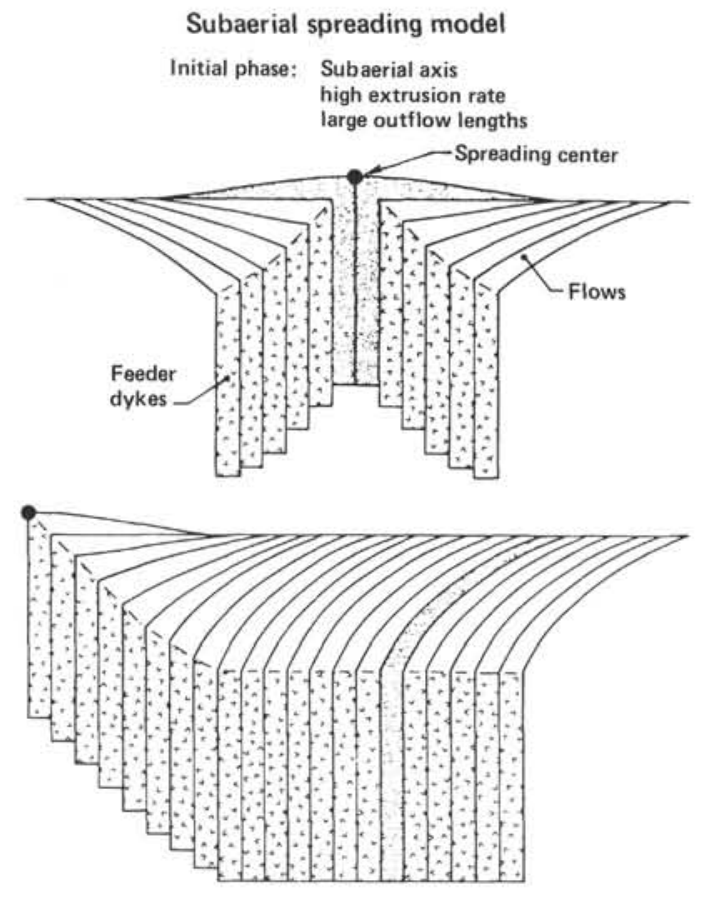

Late phase: Normal axis depth and extrusion rate Small flow lengths
Stretching/intrusion model

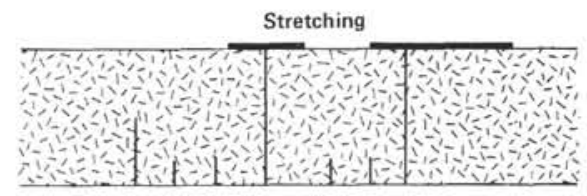

Dyke intrusion of lower crust; initiation of stretching: first subaerial eruptions.
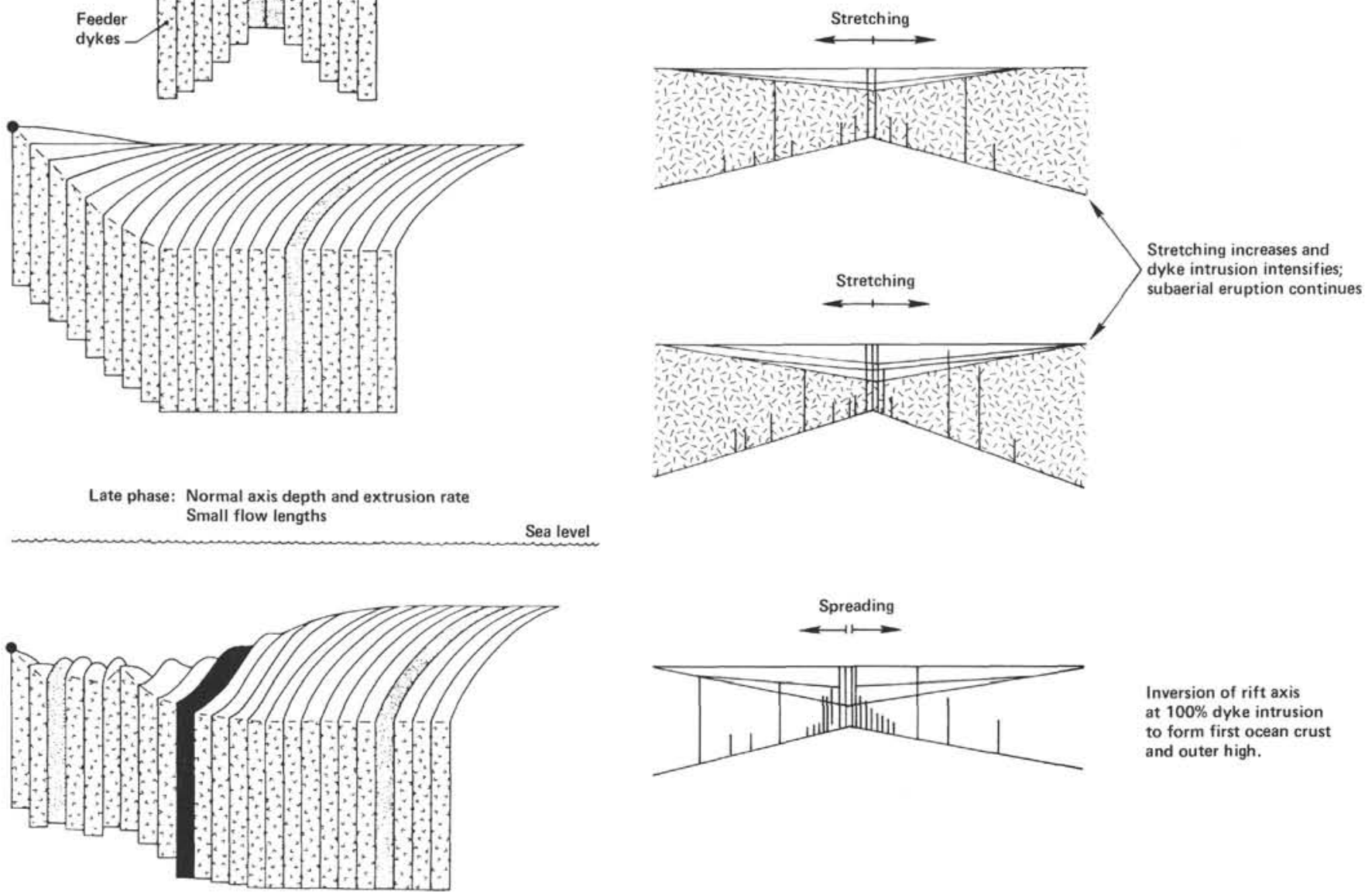

Inversion of rift axis at $100 \%$ dyke intrusion to form first ocean crust and outer high.

Figure 19. Comparison of the Mutter et al. (1982) model of "subaerial" spreading and the proposed model of dyke intrusion throughout stretching area.

Jones, M. T., and Roberts, D. G., 1975. Magnetic anomalies in the North East Atlantic. Abst. Mtg. Europ. Geol. Soc. Reading.

Kharbouch, F., 1982. Petrographie et geochemie des lavas dinantienne de la Meseta nord occidentale et nord-orientale marocaine [These de $3^{\circ}$ cyclel. Université de Strasbourg, France.

Langseth, M., and Zielinski, G. W., 1974. Marine heat flow measurements in the Norwegian-Greenland Sea and the vicinity of Iceland. In Kristjannson, L. (Ed.), Geodynamics of Iceland and the North Atlantic Area: Dordrecht (D. Riedel), pp. 277-295.

Larsen, H. C., in press. Geology of the East Greenland Shelf. Proc. NT.P Symp., Trondheim.

Laughton, A. S., 1971. South Labrador Sea and the evolution of the North Atlantic. Nature (London), 232:612-617.

Le Pichon, X., Francheteau, J., and Mascle, J., 1976. Plate Tectonics: Amsterdam (Elsevier).

McKenzie, D. P., 1978. Some remarks on the development of sedimentary basins. Earth Planet. Sci. Lett., 40:25-32.

Miller, J. A. M., Roberts, D. G., and Matthews, D. H., 1973. Rocks of Grenville age from Rockall Bank. Nature Phys. Sci., 246:61.

Montadert, L., Roberts, D. G., et al., 1979. Init. Repts. DSDP, 48: Washington (U.S. Govt. Printing Office).

Montadert, L., Roberts, D. G., de Charpal, O., and Guennoc, P., 1979. Rifting and subsidence of the northern continental margin of the Bay of Biscay. In Montadert, L., Roberts, D. G., et al., Init. Repts. DSDP, 48: Washington (U.S. Govt. Printing Office), 1025-1060.

Mutter, J., 1982. Rifting of the Norwegian margin and young ocean basin accretion dynamics in the Norwegian-Greenland Sea [Ph.D dissert.], Columbia University, New York.

Mutter, J., Talwani, M., and Stoffa, P. L., 1982. Origin of seaward dipping reflectors in oceanic crust off the Norwegian margin by "subaerial sea-floor spreading." Geology, 10:353-357.

Nielsen, T. F. D., and Brooks, C. K., 1981. The East Greenland rifted continental margin, An examination of the coastal flexure. J. Geol. Soc. London, 138:559-568.

Palmason, G., 1980. A continuum model of crustal generation in Iceland: Kinematic aspects. J. Geophys. 47:7-18.

Parsons, B., and Schlater, J. G., 1977. An analysis of the variation of ocean floor bathymetry and heat flow with age. J. Geophys Res., 81:2997-3006.

Roberts, D. G., 1974. Structural development of the British Isles, continental margin and the Rockall Plateau. In Burk, C. A. and Drake, C. L. (Eds.), The Geology of Continental Margins: New York (Springer-Verlag), pp. 343-359.

1975. Marine geology of the Rockall Plateau and Trough. Phil. Trans. R. Soc. London., 278:447-509. 
Roberts, D. G., Ardus, D. A., and Dearnley, R., 1973. Pre-Cambrian rocks drilled from the Rockall Bank. Nature. Phys. Sci., 244:21-33.

Roberts, D. G., Flemming, N. C., Harrison, R. K., and Binns, P., 1973. Helen's reef: A Cretaceous microgabbroic intrusion in the Rockall intrusive center. Mar. Geol., 16:M21-M30.

Roberts, D. G., and Ginzburg, A., 1984. Deep crustal structure of southwest Rockall Plateau. Nature, 308:435-437.

Roberts, D. G., Masson, D. G., and Miles, P. R., 1981. Age and structure of the southern Rockall Trough: New evidence. Earth Planet. Sci. Lett., 52:115-121.

Roberts, D. G., Matthews, D. H., and Eden, R. A., 1972. Metamorphic rocks from the southern end of Rockall Bank. J. Geol. Soc. London, 128:501-506.

Roberts, D. G., and Montadert, L., 1980. Contrast in the structural style of the passive margins of Biscay and Rockall. Phil. Trans. R. Soc. London, Series A, 294:97-104.

Roberts, D. G., Montadert, L., and Searle, R. C., 1979. The Western Rockall Plateau stratigraphy and structural evolution. In Montadert, L., Roberts, D. G., et al., Init. Repts. DSDP, 48: Washington (U.S. Govt. Printing Office), 1061-1088.

Roberts, D. G., and Whitmarsh, R. B., 1968. A bathymetric and magnetic survey of the Gulf of Tadjura, Western Gulf of Aden. Earth Planet. Sci. Lett., J:235-258.

Schilling, J. G., and Noe-Nygaard, A., 1974. Faeroe-Iceland plume: Rare-earth evidence. Earth Planet. Sci. Lett., 24:1-14.

Scrutton, R. A., 1970. Results of a seismic refraction experiment on Rockall Bank. Nature, London, 227:826-827.

1972. The structure of Rockall Plateau microcontinent. Geophys. J., 27:259-275.

Scrutton, R. A., and Roberts, D. G., 1971. Structure of the Rockall Plateau and Trough, North East Atlantic. ICSU/SCORWG31 Sym- posium, Cambridge, 1970: The geology of the East Atlantic Continental Margin. Inst. Geol. Sci. Rept., 70/14(2):77-87.

Soper, N. J., Higgins, A. C., Downie, C., Matthews, D. W., and Brown, P. E., 1976. Late Cretaceous-early Tertiary stratigraphy of the Kanger lugssuaq area, east Greenland and the age of opening of the north east Atlantic. J. Geol. Soc. London, 132:85-104.

Srivastava, S. P., 1978. Evolution of the Labrador Sea and its bearing on the early evolution of the North Atlantic. Geophys. J., 52: 313-357.

Talwani, M., Mutter, J., and Eldholm, O., 1981. Initiation of the opening of the Norwegian Sea. Oceanologica Acta, No. SP, 23-30.

Thompson, R. N., 1982. Geochemistry and magma genesis (Part 7: The British Tertiary province). In Sutherland, D. S. (Ed.), Igneous Rocks of the British Isles: London (Wiley and Sons), pp. 461-477.

Vierbuchen, R. C., George, R. P., and Vail, P. R., 1983. A thermal mechanical model of rifting with implications for outer highs on passive continental margins Mem. Am. Assoc. Pet. Geol., 34: 765-780.

Vogt, P. R., and Avery, O. E., 1974. Detailed magnetic surveys in the northeast Atlantic and Labrador Sea. J. Geophys. Res., 79:363-389.

Von Herzen, R. P., and Maxwell, A. E., 1959. The measurement of thermal conductivity of deep sea sediments by a needle-probe method. J. Geophys. Res., 64:1557-1563.

Wager, L. R., 1934. Geological investigations in East Greenland Part 1: General geology from Angmagssalik to Kap Dalton. Medds. Groland, 105:1-46.

Watts, A. B., and Ryan, W. B. F., 1976. Flexure of the lithosphere and continental margin basins. Tectonophysics, 36:25-44.

Ziegler, P. A., 1978. Northwestern Europe: Tectonics and basin development. Geologie Mijnb., 57:589-626.

Date of Acceptance: March 7, 1984 